\title{
Magis rythmus quam metron: \\ the structure of Seneca's anapaests, and the oral/aural nature of Latin poetry ${ }^{1}$
}

Lieven Danckaert, Ghent University.

Prefinal draft, September 2013 (to appear in Symbolae Osloenses).

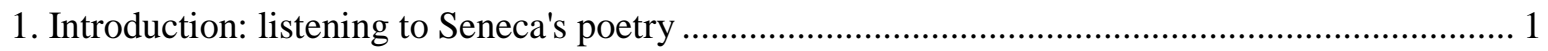

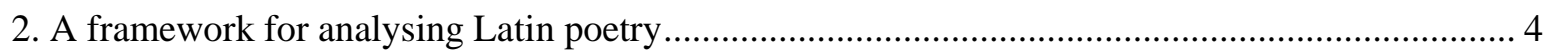

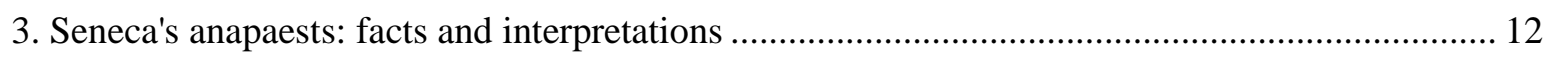

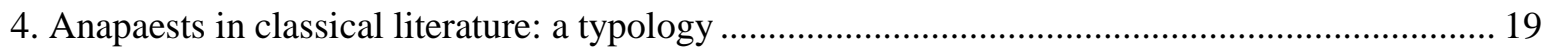

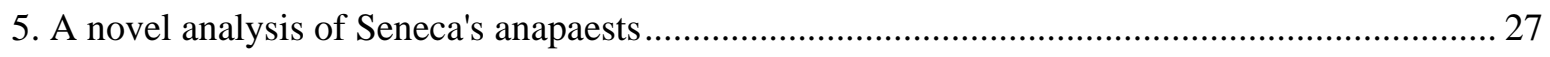

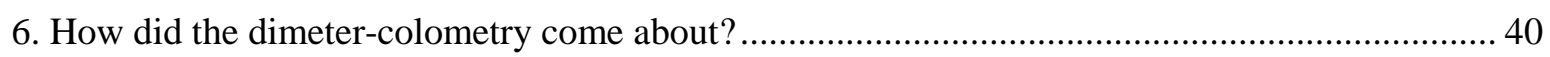

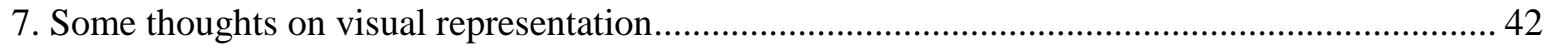

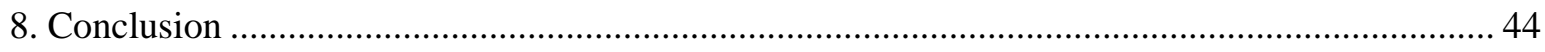

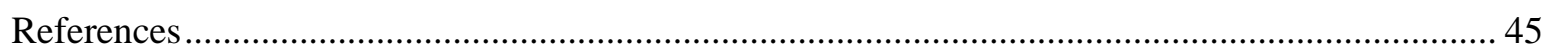

\begin{abstract}
The aim of this contribution is twofold. The empirical focus is the metrical structure of Seneca's anapaestic odes. On the basis of a detailed formal analysis, in which special attention is paid to the delimitation and internal structure of metrical periods, I argue against the dimeter colometry traditionally assumed. This conclusion in turn is based on a second, more methodological claim, namely that in establishing the colometry of an ancient piece of poetry, the modern metrician is only allowed to set apart a given string of metrical elements as a separate metron, colon or period, if this postulated metrical entity could 'aurally' be distinguished as such by the hearer.
\end{abstract}

keywords: metre, rhythm, Seneca, anapaests, orality

\section{Introduction: listening to Seneca's poetry}

\subsection{Seneca's anapaests}

This paper is concerned with the metrical structure of the anapaestic odes from the tragedies attributed to Lucius Annaeus Seneca. ${ }^{2}$ Except for the Phoenissae, all of these plays consist of spoken dialogues and sung or recited cantica. The metre used in the spoken parts (the socalled diuerbia) is the iambic trimeter, whereas the choral and monodic hymns are composed

\footnotetext{
${ }^{1}$ I would like to thank Yanick Maes for originally drawing my attention to Seneca's tragedies.

${ }^{2}$ As is well known, the authenticity of two of these plays is disputed: in the case of the Hercules Oetaeus, scholars tend to question Seneca's authorship, and it is almost certain that the Octauia was not written by Seneca.
} 
in a variety of metres, mainly anapaests and some of the lyrical metres used by Horace. ${ }^{3} \mathrm{~A}$ short excerpt from an anapaestic passage is given in (1), with the colometry of Zwierlein's OCT-edition (Sen. Phaed. 1-9): ${ }^{4}$

(1) $-\ldots--1-u v--1$

Ite umbrosas cingite siluas

$-\quad \cup \quad-\quad$ I $\cup \cup-\cup \cup-1$

summaque montis iuga Cecropii!

$\cup \cup---\mid--\cup \cup-1$
celeri planta lustrate uagi

$-\quad--\mid \cup \cup---1$

quae saxoso loca Parnetho

- $-u \cup-1$

subiecta iacent,

$-\quad-\cup \cup-1-\cup \cup-\quad-1$

quae Thriasiis uallibus amnis

$\cup \cup---1-\cup \cup--1$

rapida currens uerberat unda

$-\cup \cup--1-\quad---1$

scandite colles semper canos

$\cup \cup--1$

niue Riphaea.

'Go, surround the shadowy forests and the high ridges of Cecrops' mountains. Roam across the lands that lie below the rocky Parnethus, and those that are battered by the river in the valley of Thria, as it rushes with its strong-flowing current. Climb the hills, always white with Riphaean snow!'

The smallest building block of passages like (1) is the anapaestic metron, which consists of 4 elements. ${ }^{5}$ The basic template is given in (2):

(2) $\sigma-\sigma-1$

In the Senecan tragedies, the first three elements can be realized by either a long syllable or by two short ones, with the proviso that the second element can only appear as a double short if the first element is realized as a long syllable. The abstract pattern in (2) can thus take the following shapes:

(3) 1 .

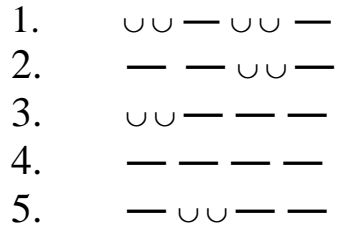

$$
\mid
$$

$\begin{array}{ll}= & \mathrm{AA} \\ = & \mathrm{SA} \\ = & \mathrm{AS} \\ = & \mathrm{SS} \\ = & \mathrm{DS}\end{array}$

Two additional descriptive generalizations need to be made. First of all, each of all the 3388 anapaestic metra in the Senecan corpus is followed by a caesura. ${ }^{6}$ In other words: the end of a metron systematically coincides with the end of a word. Second, the phenomenon of catalexis is completely (and conspicuously) absent.

\footnotetext{
${ }^{3}$ The reader is referred to Zwierlein (1986, 464-469) for a detailed conspectus metrorum, and to Dangel (2001, 292) for the frequencies of the different metres per play.

${ }^{4}$ In the metrical transcriptions, the following symbols are used: $\cup=$ light syllable; $-=$ heavy syllable; $:=$ regular caesura; $\mid=$ (almost) obligatory caesura; $\|=$ period end, $\mathbf{H}=$ hiatus, $\mathbf{B}=$ breuis in longo; (cat.) = catalexis; // = change of speaker. Further abbreviations used include A for anapaest, S for spondee and D for dactyl. All citations from Seneca's tragedies, including the colometry, are from Zwierlein's OCT-edition, unless explicitly mentioned otherwise. All translations of Latin and Greek fragments are mine, unless mentioned otherwise.

${ }^{5}$ On the technical definition of this concept, see section 2.1.2.

${ }^{6}$ See section 2.3.3 for an exact definition of how the term 'caesura' is used throughout this study.
} 


\subsection{The problem}

It is commonly assumed that the basic structural unit of Seneca's anapaestic cantica is the anapaestic dimeter (i.e. a combination of two anapaestic metra), and that in cases where an anapaestic poem consists of an odd number of metra, one or more monometers are inserted among the dimeters. Furthermore, there seems to be a consensus that these dimeters and monometers are metrically independent verses. Importantly, however, there is no consensus as to the correct colometry of the anapaestic odes, neither in the medieval manuscripts nor among modern philologists. More specifically, the exact number and location of the anapaestic monometers is the subject of much debate. For instance, the 7 anapaestic metra of Phaedra 5-9 are laid out in Fitch's LCL edition as in (4), with scandite colles as a monometer rather than niue Riphaea (as in Zwierlein's edition), whereas neither of these two metra are represented as monometers in any of the preserved manuscripts.
(4) quae Thriasiis uallibus amnis
rapida currens uerberat unda;
scandite colles
semper canos niue Riphaea.

Much of the literature on Seneca's anapaests is devoted to the question as to which (and therefore also how many) anapaestic metra are to be singled out as monometers. In say the last 130 years, two tendencies can be observed: on the one hand, scholars tend to more and more alter the colometry of the manuscripts (viz. by inserting more monometers), and on the other hand, more and more attention is paid to the relation between certain rhythmical patterns and sense-units. A detailed overview of the secondary literature on this topic is provided in section 3 below.

\subsection{The analysis in a nutshell}

The main claim of this paper is that in the Senecan tragic corpus, the anapaestic dimeter cannot be considered an independent verse or colon. The chief argument to support this claim is that the acoustic clues that are necessary to enable the hearer to identify dimeter units as such are either too weak or completely absent. Instead, I propose that the anapaestic metron is the basic constitutive element of the anapaestic odes (cf. Müller [1861] 18942), and that it derives its status as an auditorily recognizable unit from the fact that it is always followed by a caesura. In addition, and departing from Müller's analysis, I suggest that the single metron is not to be granted the status of an independent period (say a 'verse'). Rather, in most cases anapaestic metra are concatenated to form larger units that are structurally very similar to systemic periods that we know from Greek lyric poetry and early Roman comedy. From a purely formal metrical point of view, there is no relevant level of analysis in between the single metron and these large periods. The present account essentially follows the analysis of Greek recited anapaests proposed by Wilamowitz $(1910,1921)$ and West (1977).

An important insight which has repeatedly been stressed by many scholars is that Seneca had a predilection for mapping self-contained sense-units onto certain rhythmical patterns. $^{7}$ Departing from what seems to be the communis opinio on this subject, I will propose that the units thus formed are real, but that they can only be considered 'stylistic cola' (West 1977, 94), which have much in common with the prose cola identified by Fraenkel (1932-33) and Habinek (1985).

\footnotetext{
${ }^{7}$ See especially Richter (1899) and Fitch (1987).
} 
At a more general level, the paper is also a plea for careful formal analysis in approaching ancient poetry, and for fully taking into account the crucial structuring role of those elements that could aurally be distinguished by the ancient hearer, especially caesurae and pauses. As we will see below, the former play a key role in articulating the internal structure of metrical periods, whereas the latter allow the hearer to separate periods from one another.

The remainder of this paper is structured as follows. Section 2 provides the theoretical background: a formal framework is developed which allows us to accurately predict under which conditions a string of metrical elements can aurally be perceived as an autonomous metrical constituent. Section 3 offers a theory-neutral description of the anapaestic passages in Seneca's tragedies, as well as an overview of the secondary literature on the topic. In section 4, I discuss three different ways in which anapaests are used in Greek and Latin poetry, paying special attention to the presence or absence of dimeter units. In section 5, I present my analysis of Seneca's anapaests. I propose that the traditional dimeter colometry cannot be defended, since dimeter units do not qualify as constituents that can be distinguished by the ear. Instead, I suggest that the basic unit is the single anapaestic metron, which in most cases is part of a longer systemic structure. I conclude this analytic section with some remarks concerning the much-discussed distinction between rhythm and metre. Finally, I briefly consider the question as to how the dimeter traditional colometry might have come about (section 6), and I discuss some possible ways in which Seneca's anapaests can be visually represented in a text edition (section 7). Section 8 concludes.

\section{A framework for analysing Latin poetry}

\subsection{Non oculis sed auribus}

\subsubsection{The oral/aural nature of Latin poetry}

Much of the upcoming argumentation is based on the assumption that in the particular case of Latin (and Greek), both the external delimitation and the internal organization of metrical constituents are solely determined by audible signals. As this assumption is so crucial, I will first elaborate on the reasons that motivate it.

The main argument in support of an 'acoustic' approach to Latin metre is the wellknown fact that in Roman society, literature was typically read aloud. In the words of Kenney (1982: 12):

"In general it may be taken for granted that throughout antiquity books were written to be read aloud, and that even private reading often took on some of the characteristics of a modulated declamation. [footnote omitted] It might be said without undue exaggeration that a book of poetry or artistic prose was not simply a text in the modern sense but something like a score for public or private performance."

This and other similarly strong statements about the orality of literary practice (as well as of reading in general, cf. Balogh 1927) have been met with quite some criticism. For instance, it has been pointed out that there is good evidence for silent reading of private documents (letters and other non-literary texts) (see Knox 1965 and Gilliard 1993, and references cited there). However, it is not clear whether this (indeed convincing) evidence can be carried over to literary texts (especially poetry). Nowadays, the consensus position seems to be that literary Latin was typically but not exclusively read aloud, and that variation between different modalities of delivery were mainly conditioned by sociological factors (Johnson 2000). Thus Parker (2009: 187): "As the evidence [...] make[s] clear, the Romans enjoyed poetry (and literature in general) in four basic ways, each with its own social parameters: in recitations, as entertainments at convivia, through professional lectors, and by private reading." 
It therefore seems safe to assume that, even if not all private reading (of literary or nonliterary texts) was done aloud, Seneca's tragedies were written to be at the very least compatible with oral performance (which was presumably the default), which in turn is sufficient to warrant the assumption that the identification of metrical units has to depend on audible rather than visible signals. ${ }^{8}$ Quite independent of the much-debated question as to whether Seneca's dramas were meant to be performed on stage or merely recited (which is of course orthogonal to the point at issue), I shall therefore take it for granted that Seneca's prototypical 'addressee' was a hearer rather than a reader.

\subsubsection{Parsing metrical structure}

As in all cases of oral communication, it is the hearer's task to parse the incoming stream of sound into smaller units. Assuming a(n informal) definition of poetry as the organization of language into structural units (say 'lines', or 'verses') which are not present in everyday language, we can say that in the particular case of poetry, this parsing has to be done at two different levels, viz. the syntactic and the additional poetic level. But what exactly does this additional level look like?

In metrical ${ }^{9}$ poetic systems, like the ones we know from Sanskrit, Ancient Greek and Latin, restrictions are imposed on the (i) size and (ii) internal make-up of structural units. In these systems, the size of metrical units is calculated on the basis of syllable quantities. Moreover, heavy and light syllables usually appear in a certain order: some people refer to a less rigidly ordered pattern as rhythm (which is found in certain forms of literary prose), and to a more rigid ordering as metre. ${ }^{10}$ On the basis of the remarks in the previous section, it seems natural to suppose that in the case of (Classical) Latin poetry, these structural units are to be defined in terms of audible signals. Throughout the upcoming discussing, I will assume that in analysing Latin poetry, it is important to take into account both (i) the external structure of metrical constituents (i.e. the way in which structural units are set apart from one another), and (ii) the internal make-up of constituents (i.e. the various recurring elements that create a rhythmical effect). More specifically, I will assume that in an orally performed piece of poetry, the independent character of a metrical unit $\mathrm{x}$ (i.e. the fact that $\mathrm{x}$ can in principle be represented as a separate line $)^{11}$ is conditioned by the presence of audible clues that set apart $\mathrm{x}$ from a preceding unit $\mathrm{y}$ and a following unit $\mathrm{z}$ (which themselves can but need not be structurally similar to $\mathrm{x}$ ). These external and internal structure of metrical periods will be discussed in sections 2.2 and 2.3 respectively.

\subsection{External structure of metrical periods}

\subsubsection{Preliminary remarks}

In the theoretical literature on metre, it has long since been recognized that in analysing the structure of metrical texts, it is crucial to make a distinction between the abstract verse scheme on the one hand and the different possible instantiations of this scheme on the other. The former is part of phonology/phonemics, the latter belongs to the realm of phonetics. ${ }^{12}$

\footnotetext{
${ }^{8}$ As a reviewer points out, it is conceivable, but indeed quite unlikely that identification of metrical units is only a matter of tradition (as metres used in Latin poetry were taken over from Greek).

${ }^{9}$ Fabb and Halle $(2008,1)$ make a distinction between metrical and non-metrical poetry: "In metrical poetry [...] lines must satisfy requirements on length and on the location in the line of marked syllables, and different conditions are met by different kinds of non-metrical poetry." An example of non-metrical poetry are the psalms of the Old Testament, which are based on parallelisms qua syntactic structure.

${ }^{10}$ Such a view is expressed for instance in Cic. De or. 1.70 and 3.184.

${ }^{11}$ In other words, in oral poetry, audibility of a given unit is a precondition for 'visualizability' (i.e. what Donat (2010: 22) calls 'Repräsentierbarkeit'). This generalization does not carry over to most modern (western) poetry.

${ }^{12}$ Cf. Luque Moreno (1984), who points out that this distinction was already made by for instance Aristoxenus (ca. 350 B.C.E.). Jakobson (1933) famously made a distinction between 'Vers' and 'Vortrag'. See also (among
} 
As mentioned before, both Greek and Latin poetry are based on syllable quantities. More accurately, they are based on the contrast between light and heavy syllables. ${ }^{13}$ This is a strictly binary contrast, which in Latin is also at work in determining the placement of word accents. However, it is debated whether two or more elements should be postulated at the abstract metrical level. Famously, a system with five abstract elements was proposed in Maas (1962):

\begin{tabular}{|l|c|l|}
\hline Name & Symbol & Realization \\
\hline elementum breue & $\cup$ & Always realized by a short syllable. \\
\hline elementum longum & - & $\begin{array}{l}\text { Most often a long syllable, but can also } \\
\text { appear as two short syllables ('resolution'). }\end{array}$ \\
\hline elementum biceps & $\varpi$ & $\begin{array}{l}\text { Most often two short syllables, but can also } \\
\text { appear as one long syllable ('contraction'). }\end{array}$ \\
\hline elementum anceps & $\times$ & $\begin{array}{l}\text { Realized by either one long or one short } \\
\text { syllable, or by two short syllables. }\end{array}$ \\
\hline elementum indifferens & $\frown$ & $\begin{array}{l}\text { Either one long or one short syllable. It } \\
\text { only occurs at period end, and almost } \\
\text { each period is ended by it. }\end{array}$ \\
\hline
\end{tabular}

Table 1: Metrical elements proposed in Maas (1962).

I will adopt this system in the present paper. In the sections to follow, I will first have a closer look at how the end of a period is signalled (section 2.1). Subsequently, I will investigate how periods can be structured internally (section 2.2). Where possible, I will present evidence from Seneca to illustrate some more subtle phenomena. Note that many of the technical notions used were already present in the treatises of ancient grammarians, most notably in Hephaestion's Enchiridion. However, none of the Greek or Latin grammatici managed to present a unified theory capturing all structural aspects of metrical poetry, whence the need of spelling out such a theory in some detail.

Second, throughout the discussion I will assume the following rule of thumb, formulated by Martin West (1982a, 33), essentially based on August Boeckh's (1811) edition of Pindar: "In analysing lyric poetry generally one must be guided not by ancient colometry but strictly by objective internal criteria". ${ }^{15}$ In other words, the structure and the colometry of a piece of poetry are logically independent of one another, and methodologically, it is of the utmost importance to keep the two apart. With 'structure', I shall refer to the inherent formal properties of a metrical text, which remain constant across various modes of performance and codification, and which are to be studied and analysed by the metrician. A structural analysis should be strictly objective, and aims at reconstructing the abstract verse scheme underlying the concrete realizations of a given colon or period in a particular (body of) text(s). This analysis is a precondition for establishing a colometry. The latter task belongs to the realm of the text editor (or the scribe, in earlier times), who may or may not be the same person as the above-mentioned metrician. I shall define the notion of 'colometry' as the way in which a metrical text is laid out in a manuscript or a modern text edition. A colometry depends on the editor's (per definition at least to some extent subjective) interpretation of a metrician's structural analysis: in the best case, it correctly reflects the structural properties of the text, but

many others) Jakobson (1960, 364) ('verse design' vs. 'verse instance'); Kiparsky (1975); Luque Moreno (1984); Fabb and Halle (2008).

${ }^{13}$ An open syllable containing a short vowel is light. All other syllables are heavy.

${ }^{14}$ See the discussion in section 2.2.2 for a possible exception.

${ }^{15}$ See also Stinton (1977) and Itsumi (2007). 
it never is an inherent property of it. For some texts, there might be more than one defendable colometry. Finally, especially in medieval codices, a colometry is often conditioned by downto-earth practical considerations like the width of a page or a column.

I would like to emphasize that the bulk of the upcoming discussion is concerned with the structure of Seneca's anapaests: only in section 7 will I make some (admittedly tentative) suggestions about how they might be arranged on a piece of paper, in the light of the structural analysis proposed in section 5. In the remainder of this second section, I will introduce a number of structural notions which I deem necessary for arriving at such an analysis, starting with the basic unit of analysis, which is the metrical period.

\subsubsection{The metrical period}

In Latin and Greek poetry, a metrical period can be defined as a stretch of text in which syllabification does not take into account word boundaries (West 1982a, 4-9): for instance, a word-final consonant forms a syllable with the initial vowel of the following word. This process is sometimes called 'resyllabification'. Bruno Snell $\left(1957^{2}, 3\right)$ emphasizes the importance of the period as a unit of analysis:

"[...] Perioden sind jeweils die Einheiten, von denen eine metrische Analyse auszugehen hat. Bei der Analyse lyrischer Verse ist vor allem davor zu warnen, die Teile von Perioden so zu behandeln, als ob sie selbständig existierende Stücke wären."

The prosodic continuity which enables syllabification to take place across the boundaries of words and metrical constituents is usually referred to as synaphy. ${ }^{16}$ There never is synaphy between two independent periods. The boundary between two periods is called a pause. Strictly speaking, pauses occur at the abstract level of the metrical scheme: they can but need not be signalled in the actual realization of a given scheme.

\subsubsection{Pauses and the delimitation of metrical periods}

The auditory clues by which metrical pauses can be diagnosed are three in number: hiatus, breuis in longo on the one hand and catalexis on the other. ${ }^{17}$ The first two are grouped together because they always are the realization of an elementum indifferens in the abstract metrical scheme of the period in which they occur.

2.2.3.1 Hiatus and breuis in longo Hiatus can be defined as a succession of a word-final vowel (possibly followed by $-\mathrm{m}$ ) and a word-initial vowel, which is not affected by any process of elision. The first syllable involved is almost always the realization of the abstract elementum indifferens, and hence a diagnostic of a metrical pause. ${ }^{18}$ Breuis in longo, a term coined by Paul Maas ${ }^{19}$ (shorthand for syllaba breuis in elemento longo), is the occurrence of a light syllable where internal responsion would require a heavy syllable, i.e. where an elementum indifferens at the end of period-final metron or colon alternates with an elementum longum at the end of period-internal metra or cola. This phenomenon also signals the end of a metrical period.

2.2.3.2 Catalexis The third diagnostic is the phenomenon of catalexis, which is a truncation operation by which an element which is repeated a number of times inside a period appears at the end of the period with one element less. ${ }^{20}$ Catalexis gives rise to a change of rhythm (most

\footnotetext{
${ }^{16}$ See Rossi (1978), and also the fragment of Terentianus Maurus quoted in section 4.1.1.

${ }^{17}$ See among others García Novo (1995).

${ }^{18}$ In Latin, exceptions are mainly restricted to the comic poets and to cases where the exclamative interjection $\bar{o}$ is followed by a vowel.

${ }^{19}$ Maas $(1962,29,33)$, passim.

${ }^{20} \mathrm{I}$ am abstracting away from hypercatalexis, which adds an element at the end, and which has essentially the same effect as catalexis.
} 
often, a period internal sequence $u-$ appears as $-v$ at the end, and uice uersa). ${ }^{21}$ One usually makes a distinction between catalectic (i.e. truncated) and acatalectic (i.e. full) periods. Since it never appears inside a period, catalexis is a reliable diagnostic for a pause.

Importantly, the three phenomena of hiatus, breuis in longo and catalexis have one crucial property in common: they provide an audible signal indicating to the hearer that a period has come to an end. Having discussed the external structure of metrical periods, I now turn to their internal make-up.

\subsection{Internal structure of metrical periods}

\subsubsection{Metra and cola}

Longer metrical periods can often be subdivided into smaller, often recursive, units. They are either metra (sg. metron) or cola (sg. colon). A metron is either a single foot, as in the dactylic hexameter or the iambic senarius, or a combination of two feet (also called a dipody, Gr. $\left.\delta i \pi \delta^{\prime} i \alpha\right)$, as in the trochaic tetrameter or the iambic trimeter. The notion of 'colon' is defined by West (1982a, 5-6) as "[...] a single metrical phrase of not more than about twelve syllables. Certain types of colon are capable of being used as verses (short periods), but in general cola are subdivisions of periods. What gives them their identity is primarily their reappearance in other contexts, either in the same or in other compositions." We can thus make a distinction

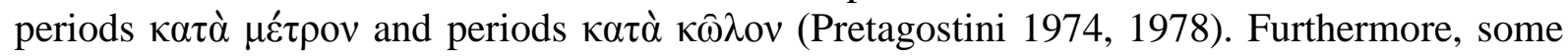
periods are made up of both metra and cola. An example of this last structure is given in (5) (Ar. Ran. 241-9):

(5)

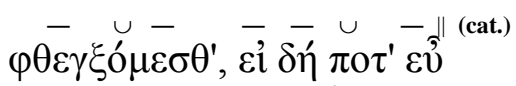

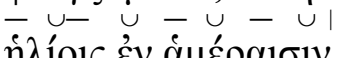

$$
\begin{aligned}
& \eta \lambda \text { iols } \varepsilon \nu \alpha \mu \varepsilon \rho \alpha 1 \sigma i v
\end{aligned}
$$

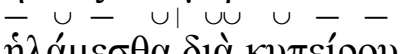

$$
\begin{aligned}
& \dot{\eta} \lambda \alpha ́ \mu \varepsilon \sigma \theta \alpha \delta \dot{\alpha} \kappa v \pi \varepsilon i ́ p o v
\end{aligned}
$$

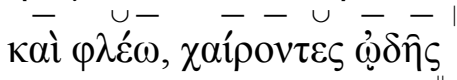

$$
\begin{aligned}
& \cup \cup \cup{ }_{-} \cup \cup \cup \cup \| \text { (cat.) }
\end{aligned}
$$

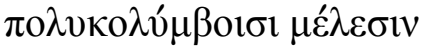

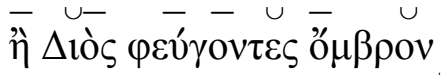

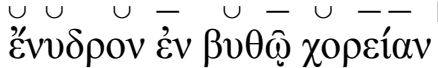

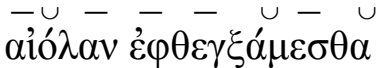

$$
\begin{aligned}
& \text { - } \cup \cup \cup-\ldots \cup \cup \| \text { (cat.) } \\
& \pi о \mu \varphi о \lambda v \gamma о \pi \alpha \varphi \lambda \alpha \dot{\sigma} \mu \alpha \sigma v \text {. }
\end{aligned}
$$

'We will make <even more> noise, if ever on sunny days we hopped through sedge and reed, rejoicing in the diving melodies of our song, or if we ever fled from Zeus's rain to sing a choral song deep under the water, with bubbly ploppifications. ${ }^{.22}$

The three periods in this fragment, each with a catalexis at the end, consist of trochaic dimeters. They are built $\kappa \alpha \tau \grave{\alpha} \mu$ ś $\rho \rho v$, the single metron being a trochaic dipody $(-\cup-\times)$. In addition, the two last periods are also $\kappa \alpha \tau \dot{\alpha} \kappa \hat{\omega} \lambda \mathrm{ov}$, with the acatalectic colon having the following shape: $-u-x-\cup-\times \mid$. The recognizability of the dimeter cola is mainly ensured through the (non-)realization of caesurae: all cola are followed by a caesura, but in only one of them (1. 243), there also is a caesura after the first metron.

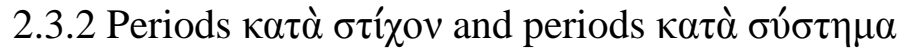

The main difference between stichic periods and systems is their respective length: systems are usually much longer than $\sigma \tau$ íxor. A second difference resides in the fact that there is a

\footnotetext{
${ }^{21}$ For a general discussion of the phenomenon, see West (1982b, 281-286).

${ }^{22}$ The translation is based on Henderson (2002).
} 
closed class of more or less fixed $\sigma \tau i$ íot, which usually are repeated many times. Systems are very often unique ad hoc compositions, and they are strongly associated with lyrical poetry. When systems are repeated at all, the number of repetitions remains fairly small. In those cases, they are usually called strophes (the identical repetition of which is referred to as 'strophic responsion').

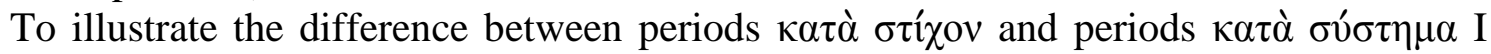
would like to analyse two stretches of dactylic tetrameters from Seneca, one from the Oedipus, and one from the Hercules Oetaeus. Let us start with the former:

(6)

Te Tyrrhena, puer, rapuit manus,

- $\cup \cup$ - _ - $\cup \cup-\cup \cup \|$

et tumidum Nereus posuit mare,

- $\cup$ - $\quad$ - $~-~ \cup \cup \|$

caerula cum pratis mutat freta: $\mathbf{H}$

450

hinc uerno platanus folio uiret

- $\quad-\quad-\quad--\cup \cup \|$

et Phoebo laurus carum nemus;

$-u \cup-$ - $-u \cup-u \cup \|$

garrula per ramos auis obstrepit;

$-\ldots \cup \cup-\ldots u \|$

uiuaces hederas remus tenet,

- $\cup \cup-\ldots-\quad-\cup \cup \|$

summa ligat uitis carchesia. $\mathbf{H}$

Idaeus prora fremuit leo,

$-\quad-\quad u \cup-\quad-\quad-\cup \cup \|$

tigris puppe sedet Gangetica.

- - - $\cup \quad \cup-u \cup-u \cup \|$

Tum pirata freto pauidus natat,

$-u v-\ldots$ - $u v-u v \|$

et noua demersos facies habet:

- $u-\cup \cup-\quad-\quad u \cup \|$

bracchia prima cadunt praedonibus

- - - $\cup \cup-\ldots$ - $\cup \cup \|$

inlisumque utero pectus coit,

- $\cup \cup-\ldots$ - $\cup \cup-u \cup \|$

paruula dependet lateri manus,

$-\quad----\quad \cup \cup \|$

et dorso fluctum curuo subit,

$---\quad-\quad-\quad \cup \cup \|$

lunata scindit cauda mare: $\mathbf{H}$

$-u \cup-\ldots u \cup-\cup u \|$

et sequitur curuus fugientia

$-\cup \cup-\|_{23}$
carbasa delphin. $^{23}$

460

'People from Tyrrhene once seized you, boy. Nereus appeased the swollen sea and transformed the deep-blue sea into meadows. Then there were plane trees with green foliage and laurels, groves dear to Apollo, and birds singing cheerfully among the branches. The oars were covered with fresh ivy, grapevines clung to the top of the mast. A lion from Ida roared near the prow, a tiger from the Ganges sat at the stern. Then the pirates anxiously swam in the sea, and as they sunk, they start changing shape: their

\footnotetext{
${ }^{23}$ These last two feet (1. 466B) form a so-called adoneus, which is used by both Horace and Seneca as clausula ending a Sapphic stanza. Metrically, it is identical to the last two feet of a dactylic hexameter. It was Gustav Richter who proposed to split up line 466, a dactylic hexameter with a bucolic caesura, into a tetrameter and an adoneus: the manuscripts all represent it as one line. However, I don't see how a hearer could possibly not percieve the sequence 'dactylic tetrameter + adoneus' as a dactylic hexameter.
} 
arms fall of, their chests are joined to their bellies, small hands hang at their sides. Curving backs dive into the waves, moon-shaped tails cut through the sea and curved dolphins follow the ship's fleeing sails.' (= Sen. Oed. 449-466)

The three instances of interlinear hiatus give us a first indication that we are dealing with stichic periods. Furthermore, if the above fragment were systemic, there would be five cretic $(-\cup-)$ feet interspersed with the dactyls and spondees (with the 'offending' syllables marked in boldface): this is generally disallowed in any dactylic metre. Observe however that all the syllables in boldface contain a short vowel: not one of them is a(n open or closed) syllable with a long vowel or a diphthong. If we assume that they are all followed by a metrical pause and not by a word starting with a consonant (cf. the non-availability of synaphy between two periods, mentioned in section 2.2.1), the dactylic nature of the passage is guaranteed. One only needs to make the auxiliary assumption that Seneca considered closed syllables with a short vowel somehow lighter than a syllable with a long vowel, and that he wanted to avoid a cretic in the last foot. If this analysis is on the right track, this passage contains stichic verses whose last element exceptionally is a breue and not an indifferens.

The (pseudo-Senecan?) dactylic fragment of the Hercules Oetaeus shows a very different picture:

Unde sonus trepidas aures ferit?

$-u v-u v-u v-u v$

unde meas inhibet lacrimas fragor?

1945

agnosco agnosco victum est chaos.

- $u \cup-u \cup-u \cup-u \cup \mid$

a Styge, nate, redis iterum mihi

$-\cup \cup \quad \cup \cup \quad-\quad-\cup u$

fractaque non semel est mors horrida?

$--\ldots-\ldots,-\cup \cup$

uicisti rursus noctis loca

$-u \cup-\ldots-u \cup-u v 1$

puppis et infernae uada tristia?

1950

peruius est Acheron iam languidus

$-\cup \cup-\cup \cup-\ldots-\cup \cup$

et remeare licet soli tibi,

$-\quad-u \cup-\quad-\quad-u \cup \|$

nec te fata tenent post funera? $\mathbf{H}$

$-\cup \cup \quad--\quad--\cup \cup \mid$

an tibi praeclusit Pluton iter

- $\cup \cup-\ldots$ - $u \cup-\cup \cup$

et pavidus regni metuit sibi?

1955

certe ego te uidi flagrantibus

- $\cup \cup-\ldots-\ldots \quad-\cup \cup \mid$

impositum siluis, cum plurimus

- - - $\cup \cup-\ldots \quad-u \cup \mid$

in caelum fureret flammae metus:

- - - - - - - $\cup$ |

arsisti certe, cur ultima

$-\quad \cup \cup-u \cup-\ldots \quad-u \cup \mid$

non tenuere tuas umbras loca?

1960

quid timuere tui manes, precor?

- $u v---u v-u v \mid$

umbra quoque es Diti nimis horrida?

'Whence the sound that hits my frightened ears? Whence the shout that holds back my tears? Now I know, I understand: chaos has been defeated! My son, you return to me 
from the Styx, not just once you crushed horrendous death. Again you conquered night's dwellings and the sad waters of the underworld ship. Is Acheron calm and crossable these days, or is it only you who can pass? Doesn't fate have power over you even after death? Or did Pluto block your path, fearing for his kingdom, scared for himself? For sure I saw you lying on the burning logs, as fear and flames rose high into the sky. For sure you were scorched: why could the final dwelling not refrain your shadow? I ask you, what was it about you that the ghosts were afraid of? Is even your shade too grim for Dis?' (= Sen. Her. O. 1944-1962)

This passage clearly falls apart in at least two periods, separated by a hiatus. But are these the only periods or does each line constitute an independent metrical unit? Observe that the whole fragment contains 10 tetrameters that end with a light syllable (an open syllable with a short vowel). The other 9 lines end with a closed syllable with a short vowel, highlighted again in boldface. Crucially, all of those 9 closed syllables are followed by a word with an initial vowel, and only 1 of the lines that follows one of the 10 final short syllables begins with a vowel (yielding the one hiatus). If we assume that we are dealing with two periods made up of tetrameters $\kappa \alpha \tau \grave{\alpha} \sigma \dot{\sigma} \sigma \eta \mu \alpha$, it would follow, given synaphy and resyllabification (cf. section 2.1.1), that the consonants at line-end are reanalysed as the onset of the first syllable of the following line. Under this logic, all the 19 tetrameters can be said to end with a genuine light syllable. It seems therefore most likely that, despite their many similarities, the two dactylic passages are very different in one important aspect, namely the status of the tetrameter-unit: in the first passage it is an independent period, in the second it is probably a colon, which is part of a larger systemic period.

\subsubsection{A note on caesurae}

West (1982b, 292-297) convincingly argued that the (terminological) distinction between caesurae and diaereses can be dispensed with: both can be subsumed under the name of 'caesura', to be defined as a locus in a metrical structure where word end is obligatory or statistically highly frequent. ${ }^{24}$ As we saw earlier (section 2.2 .1 ), realizing or avoiding caesurae can be exploited by the poet as a means of articulating the internal structure of metrical periods.

\section{4 'Metrical constituency': an overview}

The results of the previous sections are summarized in Table 2, which shows a typology based on the following three parameters (the last two of which are not mutually exclusive): $[ \pm \kappa \alpha \tau \dot{\alpha}$

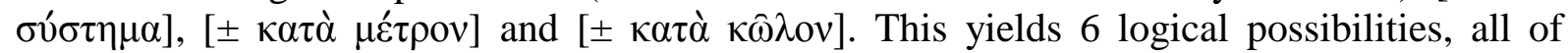
which are attested in classical poetry:

\footnotetext{
${ }^{24}$ Similarly, no such distinction is made in the literature on poetic metre outside the field of classical philology (see for instance Dominicy and Nasta 2009).
} 


\begin{tabular}{|c|c|c|c|c|}
\hline & Internal $\rightarrow$ & $\kappa \alpha \tau \grave{\alpha} \mu \varepsilon \dot{\tau} \tau \rho \nu \nu$ & $\kappa \alpha \tau \hat{\alpha} \kappa \hat{\omega} \lambda о v$ & 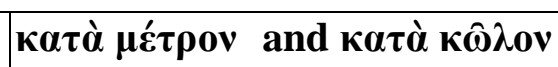 \\
\hline $\begin{array}{l}\mathbf{E} \\
\mathbf{x} \\
\mathbf{t} \\
\mathbf{e}\end{array}$ & $\kappa \alpha \tau \grave{\alpha} \sigma \tau i ́ \chi o \nu$ & $\begin{array}{l}\text { dactylic hexameters, } \\
\text { iambic trimeters, and } \\
\text { many more }\end{array}$ & $\begin{array}{l}\text { glyconei: e.g. } \\
\text { Sen. Her. F. } 875-894 \\
\text { asclepiadei: e.g. } \\
\text { Sen. Her. F. 524-591 }\end{array}$ & anapaestic tetrameters \\
\hline $\begin{array}{l}\mathbf{r} \\
\mathbf{n} \\
\mathbf{a} \\
\mathbf{l} \\
\downarrow\end{array}$ & 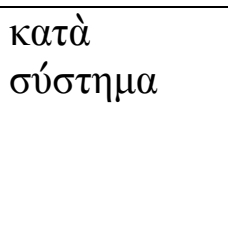 & $\begin{array}{l}\text { so-called } \sigma v \sigma \tau \eta^{\prime} \mu \alpha \tau \alpha \\
\text { '̇ ó óf } \omega v ; \text { some } \\
\text { Aristophanean } \pi v i ́ \gamma \eta: \\
\text { e.g. Nub. 1443-1451 } \\
\text { (iambic) }\end{array}$ & $\begin{array}{l}\text { choral lyric (Pindar, } \\
\text { tragedy, comedy) }\end{array}$ & $\begin{array}{l}\text { - some comic } \pi v^{\prime} \gamma \eta \text { : } \\
\text { e.g. Ar. Ran. } 241-249 \text { (troch.) } \\
\text { - some dactylic tetrameters: } \\
\text { e.g. Sen. Her. O. } 1944-1953\end{array}$ \\
\hline
\end{tabular}

Table 2: Internal and external structure of metrical periods.

Let's have a closer look at this taxonomy. First, I suppose the difference between $\kappa \alpha \tau \grave{\alpha} \mu \varepsilon \dot{\tau} \tau \rho o v$

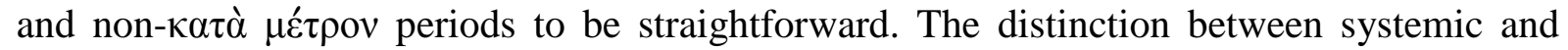
stichic periods however is a bit harder to draw, but as we have seen in section 2.3.2, elements that signal a pause (i.e. hiatus, breuis in longo and catalexis) can be used as a reliable

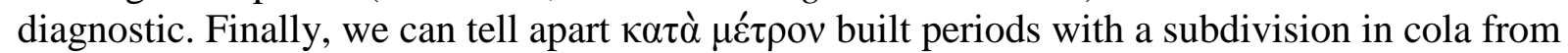
$\kappa \alpha \tau \grave{\alpha} \mu \varepsilon^{\prime} \tau \rho o v$ periods without cola by carefully inspecting the presence and location of caesurae (section 2.3.1). Crucially, both caesurae and the elements that signal a pause are not only abstract metrical entities: they could also easily be detected in the acoustic signal.

The two main research questions of this paper can now be reformulated in terms of the taxonomy in Table 2. The first is the question as to whether Seneca's anapaestic odes are built

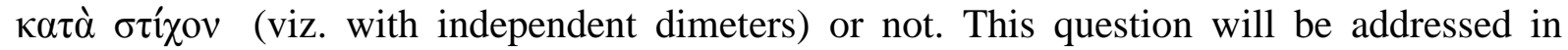

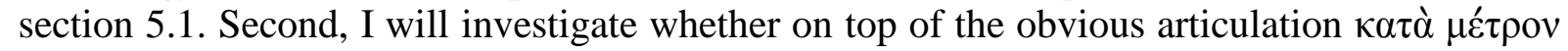
a structure $\kappa \alpha \tau \grave{\alpha} \kappa \hat{\omega} \lambda$ ov should be postulated or not (see section 5.2). I start the discussion by giving a concise formal description of Seneca's anapaestic odes. This is followed by an overview of older treatments of the problem under investigation, starting with the colometry of the medieval manuscripts, which can be considered text editions avant la lettre.

\section{Seneca's anapaests: facts and interpretations}

\subsection{Detailed formal description of the anapaestic passages}

In Seneca's tragic corpus, we find a total of 36 anapaestic passages, varying in length from 10 (Phaed. 1123-7) to 242 (Her. O. 583-705) metra. In addition, the Apocolocyntosis contains a short anapaestic nenia, which yields a total of 37 fragments and $3384^{25}$ anapaestic metra. For our purposes, the most important observation is that in the majority of the cases, two adjacent metra are united through metrical synaphy. Synaphy is not respected after 152 metra. A detailed overview is given Table 3, based on the OCT-edition of Otto Zwierlein:

\footnotetext{
${ }^{25}$ Four additional anapaestic metra appear in two of Seneca's polymetric cantica (Oed. 709 and $\left.A g .610\right)$, which brings the total to 3388 . In the rest of the paper only the passages listed in table 1 will be taken into account.
} 


\begin{tabular}{|c|c|c|c|c|}
\hline \multirow[t]{2}{*}{ nr. } & \multirow[t]{2}{*}{ passage } & \multirow[t]{2}{*}{ \# metra } & \multicolumn{2}{|c|}{ \# pauses } \\
\hline & & & per passage & per play \\
\hline 1. & Her. F. 125-201 & 155 & 4 & \multirow[b]{2}{*}{$11(320)$} \\
\hline 2. & Her. F. 1054-1137 & 165 & 7 & \\
\hline 3. & Tro. 67-163 & 188 & 9 & \multirow[b]{2}{*}{$14(249)$} \\
\hline 4. & Tro. 705-735 & 61 & 5 & \\
\hline 5. & Med. 301-379 & 155 & 4 & \multirow[b]{2}{*}{7 (264) } \\
\hline 6. & Med. 787-842 & 109 & 3 & \\
\hline 7. & Phaed. 1-84 & 157 & 6 & \multirow{5}{*}{$14(321)$} \\
\hline 8. & Phaed. 325-357 & 64 & 5 & \\
\hline 9. & Phaed. 959-988 & 59 & 2 & \\
\hline 10. & Phaed. 1123-1127 & 10 & 0 & \\
\hline 11. & Phaed. 1132-1148 & 31 & 1 & \\
\hline 12. & Oed. 154-201 & 94 & 2 & \multirow{4}{*}{$3(203)$} \\
\hline 13. & Oed. 432-444 & 25 & 0 & \\
\hline 14. & Oed. 738-763 & 51 & 0 & \\
\hline 15. & Oed.980-997 & 33 & 1 & \\
\hline 16. & Ag. 57-107 & 98 & 6 & \multirow{4}{*}{$15(343)$} \\
\hline 17. & Ag. 310-387 & 147 & 7 & \\
\hline 18. & Ag. 637-658 & 40 & 2 & \\
\hline 19. & Ag. 664-692 & 58 & 0 & \\
\hline 20. & Thy. 789-884 & 187 & 9 & \multirow[b]{2}{*}{$11(286)$} \\
\hline 21. & Thy. 920-969 & 99 & 2 & \\
\hline 22. & Her. O. 173-232 & 118 & 3 & \multirow{7}{*}{$18(601)$} \\
\hline 23. & Her. O. 583-705 & 242 & 6 & \\
\hline 24. & Her. O. 1151-1160 & 20 & 1 & \\
\hline 25. & Her. O. 1207-1217 & 22 & 1 & \\
\hline 26. & Her. O. 1279-1289 & 22 & 1 & \\
\hline 27. & Her. O. 1863-1939 & 150 & 4 & \\
\hline 28. & Her. O. 1983-1996 & 27 & 2 & \\
\hline 29. & Oct. 1-33 & 62 & 6 & \multirow{8}{*}{$56(737)$} \\
\hline 30. & Oct. 57-99 & 82 & 6 & \\
\hline 31. & Oct. 201-221 & 40 & 2 & \\
\hline 32. & Oct. 273-376 & 198 & 15 & \\
\hline 33. & Oct. 646-689 & 84 & 7 & \\
\hline 34. & Oct. $762-779$ & 36 & 3 & \\
\hline 35. & Oct. $806-819$ & 28 & 4 & \\
\hline 36. & Oct. 877-982 & 207 & 13 & \\
\hline 37. & Apocol. 12.3 & 60 & 3 & $3(60)$ \\
\hline & Total \# : & 3384 & \multicolumn{2}{|c|}{$\frac{1}{152}$} \\
\hline
\end{tabular}

Table 3: Number of metrical pauses per play and per anapaestic passage. Last column between brackets: total number of metra per play.

3.2 The manuscripts and the colometry of the anapaestic passages 
The stemma of the manuscript tradition of Seneca's tragedies is divided into two branches, traditionally called E and A. ${ }^{26}$ The E-manuscript (with 'E' for 'Etruscus') is itself preserved, but the original A-manuscript is lost. Older scholars (especially Leo 1878) used to consider E the better codex.

The basic principle behind the colometry of the anapaests in all the manuscripts is always the same: in all the codices, each line contains either one, two or three anapaestic metra. I will informally refer to such lines as monometers, dimeters and trimeters respectively. The majority of the 3384 anapaestic metra are found in dimeters, both in E and in A. However, the distribution of the monometers and trimeters is significantly different in the two manuscript families: in the E-manuscript, we find 100 monometers, compared to 62 in the A-family (which contains one more play). 22 monometers ${ }^{27}$ appear as such in both A and E. The reader is referred to Table 4 for an overview. Furthermore, 43 trimeters are found in the Etruscus, ${ }^{28}$ compared to 41 in the A-manuscripts. ${ }^{29}$ Observe that only 3 trimeters appear in both branches: they are marked in boldface in the enumerations in notes 28 and 29 .

\footnotetext{
${ }^{26}$ See Carlsson (1927) for a detailed description.

${ }^{27}$ Tro. 163; Med. 317, 328B, 379B, 811B, 816B, 839; Phaed. 977, Phaed. 1133; Oed. 179B, 750, 997; Ag. 70B, 76, 89B, 107B, 387; Thy. 969; Her. O. 232B, 603, 1916, 1996.

${ }^{28}$ The enumerations in notes 18 and 19 should be read as follows: the line number refers to the first metron of a trimeter (with A and B standing for the first and the second half of a line respectively). Between brackets, I give the number of trimeters the fragment consists of: $\underline{H e r . F}$. 1136B (1); Tro. 83A (10), 117A (10), 142A (9); $\underline{A g}$. 641A (2), 647A (1), 651A (1); Thy. 830A (1), 930B (2); Her. O. 206A (2), 623A (2), 1928A (2).

${ }^{29}$ Her. F. 1135B (1); Tro. 153B (1), 734A (1); Phaed. $42 \mathrm{~A}(27) ;$ Ag. 641A (2), 651A (1), 665A (1), 676A (2), 681B (1), 685A (1); Her. O. 218A (2); Oct. $981 \mathrm{~A}(1)$.
} 


\begin{tabular}{|c|c|c|c|c|}
\hline \multirow[t]{2}{*}{ nr. } & \multirow[t]{2}{*}{ passage } & \multirow[t]{2}{*}{ \# metra } & \multicolumn{2}{|c|}{ \# monometers } \\
\hline & & & $\mathbf{A}$ & $\mathbf{E}$ \\
\hline 1. & Her. F. 125-201 & 155 & 2 & 0 \\
\hline 2. & Her. F. 1054-1137 & 165 & 1 & 1 \\
\hline 3. & Tro. 67-163 & 188 & 3 & 1 \\
\hline 4. & Tro. 705-735 & 61 & 0 & 1 \\
\hline 5. & Med. 301-379 & 155 & 3 & 3 \\
\hline 6. & Med. 787-842 & 109 & 5 & 3 \\
\hline 7. & Phaed. 1-84 & 157 & 0 & 8 \\
\hline 8. & Phaed. 325-357 & 64 & 0 & 1 \\
\hline 9. & Phaed. 959-988 & 59 & 3 & 3 \\
\hline 10. & Phaed.1123-1127 & 10 & 0 & 0 \\
\hline 11. & Phaed. 1132-1148 & 31 & 2 & 2 \\
\hline 12. & Oed. 154-201 & 94 & 2 & 2 \\
\hline 13. & Oed. 432-444 & 25 & 0 & 1 \\
\hline 14. & Oed. 738-763 & 51 & 1 & 1 \\
\hline 15. & Oed. 980-997 & 33 & 1 & 1 \\
\hline 16. & Ag. 57-107 & 98 & 4 & 4 \\
\hline 17. & Ag. 310-387 & 147 & 1 & 49 \\
\hline 18. & Ag. 637-658 & 40 & 0 & 2 \\
\hline 19. & Ag. 664-692 & 58 & 0 & 0 \\
\hline 20. & Thy. 789-884 & 187 & 3 & 0 \\
\hline 21. & Thy. 920-969 & 99 & 3 & 1 \\
\hline 22. & Her. O. 173-232 & 118 & 1 & 5 \\
\hline 23. & Her. O. 583-705 & 242 & 2 & 2 \\
\hline 24. & Her. O. 1151-1160 & 20 & 0 & 0 \\
\hline 25. & Her. O. 1207-1217 & 22 & 0 & 0 \\
\hline 26. & Her. O. 1279-1289 & 22 & 0 & 0 \\
\hline 27. & Her. O. 1863-1939 & 150 & 2 & 8 \\
\hline 28. & Her. O. 1983-1996 & 27 & 1 & 1 \\
\hline 29. & Oct. $1-33$ & 62 & 4 & l \\
\hline 30. & Oct. 57-99 & 82 & 8 & / \\
\hline 31. & Oct. 201-221 & 40 & 2 & I \\
\hline 32. & Oct. 273-376 & 198 & 0 & I \\
\hline 33. & Oct. 646-689 & 84 & 4 & l \\
\hline 34. & Oct. $762-779$ & 36 & 0 & l \\
\hline 35. & Oct. 806-819 & 28 & 2 & l \\
\hline 36. & Oct. 877-982 & 207 & 2 & / \\
\hline & Total & 3324 & 62 & 100 \\
\hline
\end{tabular}

Table 4: Distribution of anapaestic monometers in the A and $\mathrm{E}$ branch of the manuscript tradition, per anapaestic passage.

At face value, it seems that the anapaestic cantica are laid out in the manuscripts in long stretches of dimeters, only occasionally interrupted by monometers or trimeters. Table 5 shows that the metra which do not occur in a dimeter are relatively rare in number. The 
discrepancies between the different manuscripts have led recent scholars to the conclusion that the colometry of the manuscripts is not to be relied upon. ${ }^{30}$

\begin{tabular}{|c|c|c|c|}
\cline { 2 - 4 } \multicolumn{1}{c|}{} & Total \# & \multicolumn{2}{c|}{ \# metra in } \\
metra & monometers & trimeters \\
\hline A & 3324 & $62(1,87 \%)$ & $123(3,70 \%)$ \\
\hline E & 2587 & $100(3,87 \%)$ & $129(4,99 \%)$ \\
\hline
\end{tabular}

Table 5: Absolute and relative frequency of mono-, di- and trimetric anapaestic lines in the $\mathrm{A}$ and $\mathrm{E}$ manuscripts.

I now give an overview of the different treatments that Seneca's anapaests have received in modern scholarship.

\subsection{Previous accounts}

\subsubsection{Only monometers}

Müller ([1861] $\left.1894^{2}, 106\right)$ argued that the basic unit of analysis is the monometer rather than

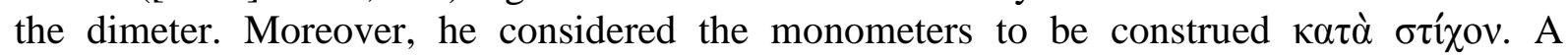
structure with anapaestic monometers $\kappa \alpha \tau \grave{\alpha} \sigma \tau i$ í $\sigma$ is not entirely unparalleled: it is attested in a number of hymns of the christian poet Synesius (born ca. 370 C.E.). However, in this particular case hiatus and breuis in longo are much more frequent than in the Senecan corpus, which makes an analysis in terms of monometers $\kappa \alpha \tau \grave{\alpha} \sigma \tau i$ qov more easy to defend in the case of Synesius. ${ }^{31}$

Only a small number of scholars has adopted Müller's analysis. ${ }^{32}$ Most philologists defend a colometry which is more in line with the manuscript tradition, with mainly dimeters and an occasional monometer. ${ }^{33}$ An early and very influential proposal is the one worked out by Friedrich Leo, in a text-critical volume accompanying his edition of the tragedies (Leo 1878-79).

\subsubsection{The anapaestic dimeter as an independent period}

Leo (1878) heavily relies on the authority of the manuscripts, and more specifically on the colometry of the E-manuscript, which he considers the bonus codex. His colometry is based on two strong assumptions. First of all, he rejects the monometer theory proposed by Müller, calling upon the manuscript tradition. Second, he denies that Seneca's anapaests are built $\kappa \alpha \tau \grave{\alpha}$

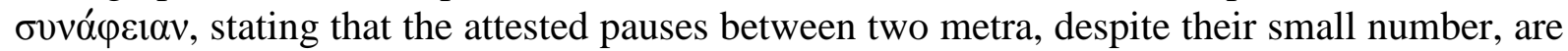
sufficient evidence for the non-systemic character of the odes. As an alternative, he proposes the following (op. cit. 99):

"[...]: unde ultro conligitur, ubi licentiam illam Seneca sibi concesserit, id in fine uersus factum esse; siue, ut rectius loquamur, non $\grave{\varepsilon} \xi$ ó $\mu$ oí $\omega v$ Senecam systemata anapaestica

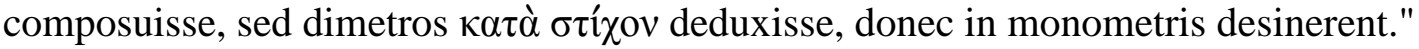

'Moreover, from this it can be concluded that wherever Seneca allowed for this licence, that it was at the end of the verse. Or, to put it more correctly, Seneca did not compose

\footnotetext{
30 Thus for instance Zwierlein (1984, 183): "Zunächst mu $\beta$ festgestellt werden, da $\beta$ die beiden Überlieferungszweige in der Kolometrie der Anapäste weit häufiger divergieren als zusammengehen; [...] da $\beta$ die Anordnung der Anapäste in den Hss zutiefst gestört ist."

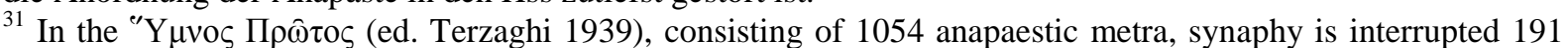
times $(=18,12 \%)$, sometimes even after 6 consecutive metra (e.g. 234-239). Compare the values for Seneca given in section 5.1.1.

32 cf. Münscher (1919, 11), Carlsson (1927, 31 n. 2) and Raabe (1912, 57).

${ }^{33}$ An early example of this can be found in Hoche (1862, 40-9).
} 


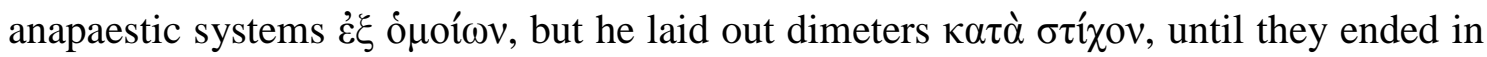
monometers.'

This statement turned out to be very influential: it is often adopted with only minor modifications $^{34}$ (many scholars do not adopt the idea that monometers function as a clausula). ${ }^{35}$

\subsubsection{The Kongruenzgesetz}

3.3.3.1 Richter 1899 Richter's Kritische Untersuchungen appeared three years before his 1902 Teubner edition, itself a revision of the 1867 edition by Richter and Peiper. In the 1899 volume, the stichic character of the anapaestic cantica is never questioned: on the basis of Leo's work, the author considers it sufficiently proven that anapaestic dimeters and monometers are independent periods. Richter then raises the following interesting question, which he immediately goes on to answer (Richter 1899, 32, emphasis mine):

"Wie soll aber der aus zwei gleichartigen Gliedern zusammengefügte anapästische Dimeter als einheitliches Ganze empfunden werden? Das ist nur möglich, wenn seine grammatische Struktur mit der metrischen zusammenfällt; [...]."

This idea forms the basis of what he calls the Kongruenzgesetz, which aims at establishing harmony between rhythmic and syntactic structure (Richter 1899, 35). Whenever two metra forming one syntactic unit are divided over two lines in the manuscripts, the colometry has to be reorganized: the two metra are put on one line and a monometer, preceding or following the newly formed dimeter, is inserted. ${ }^{36}$ Application of this reorganization procedure is independently motivated, he reasoned, since it was used by Leo to get rid of the cases where the E-manuscript exhibits a hiatus and/or a breuis in longo in the middle of a dimeter. But unlike Leo, Richter is willing to change the manuscripts' colometry even if no formal indication of a metrical pause is available (Richter 1899, 43): "Auch da ist diesem Gesetze gemäss die Abteilung zu ordnen, wo kein äusseres Merkmal - weder ein metrischer Fehler im Text, noch eine ungleichmässige Verteilung der Worte - eine Abweichung von der Ueberlieferung notwendig macht." It goes without saying that this conclusion has far-reaching consequences: it opens up the way for a massive reorganization of the manuscripts' colometry. This is exactly what happens in the Loeb-edition by John Fitch.

3.3.3.2 Fitch (1987, 2004b) The most important ingredient of Fitch's (1987) monograph is the so-called principle of sense-correspondence, which, despite the terminological nuance, can be considered a stronger version of Richter's Kongruenzgesetz. It is based on the important observation that certain instantiations of the abstract scheme of the anapaestic metron have their favourite positions at the beginning or at the end of syntactic units (or sense-units).

Fitch is mainly interested in discovering metrical patterns larger than the single metron. Note that just like Richter, he at no point questions the reality of the dimeter: dimeters and intervening monometers are presupposed throughout the entire discussion. ${ }^{37}$ On the basis of a

\footnotetext{
34 These followers include Marx (1932), Mantke (1957-58), and more recently Liberman (2005): "On dit couramment, à juste titre, que Sénèque utilise $\kappa \alpha \tau \grave{\alpha} \sigma \tau i ́ \chi o v$, c'est à dire comme des vers indépendents, non seulement le trimètre iambique, mais aussi le dimètre et le monomètre anapestique, et tous les vers lyriques."

${ }^{35}$ Leo explicitly compared the anapaestic monometer with the adoneus at the end of a sapphic stanza (Leo 1878, 99 and 101).

${ }^{36}$ The metrical status of this monometer remains unclear. Richter $(1899,32)$ : "Dieser Monometer is dann nicht als selbständiger Vers zu betrachten, sondern bildet mit den beiden zu ihm gehörigen - voraufgehenden oder folgenden - Dipodien eine Einheit."

${ }^{37}$ Fitch $(1987,5)$ :
} 
number of syntactic and stylistic criteria ${ }^{38}$, Fitch builds a mini-corpus of 301 'certain' dimeters (i.e. dimeters that clearly consist of a self-contained sense-unit), and goes on to offer a detailed metrical analysis of these. Table 6 reveals that the sequence dactyl-spondee (DS) most frequently occurs at the end of a sense-unit, whereas it is less frequent at the beginning. A double spondee has the opposite distribution. Table 7 shows that the most common dimeters are SA-DS, SS-DS and SA-SA:

\begin{tabular}{|c|c|c|}
\cline { 2 - 3 } \multicolumn{1}{c|}{} & $\mathbf{m ~ 1}$ & $\mathbf{~ m ~ 2}$ \\
\hline DS & $43(\underline{14,3 \%)}$ & $155(51,5 \%)$ \\
\hline SA & $106(35,2 \%)$ & $73(24,3 \%)$ \\
\hline SS & $72(\underline{23,9 \%)}$ & $10(\underline{3,3 \%})$ \\
\hline AA & $35(11,6 \%)$ & $41(13,6 \%)$ \\
\hline AS & $45(15,0 \%)$ & $22(7,3 \%)$ \\
\hline
\end{tabular}

Table 6: Metrical patterns in 301 anapaestic dimeters: percentages.

\begin{tabular}{|c|c|c|c|c|c|c|}
\hline & \multicolumn{5}{|c|}{ m2 } \\
\hline & & DS & SA & SS & $\mathbf{A A}$ & $\mathbf{A S}$ \\
\hline \multirow{5}{*}{ m1 } & DS & 20 & 12 & 1 & 7 & 3 \\
\hline & SA & $\underline{55}$ & 23 & 7 & 9 & 12 \\
\hline & SS & $\underline{37}$ & 16 & 0 & 15 & 4 \\
\hline & $\mathbf{A A}$ & 21 & 10 & 1 & 3 & 0 \\
\hline & $\mathbf{A S}$ & 22 & 12 & 1 & 7 & 3 \\
\hline
\end{tabular}

Table 7: Metrical patterns in 301

anapaestic dimeters: absolute figures.

The same line of reasoning is defended in Fitch (2004b). A critical evaluation will be presented in section 5 (especially 5.2.2).

\subsubsection{The distribution of the pauses}

Another editor who was willing to alter the colometry of the manuscripts is Otto Zwierlein. In his 1984 book, this author was even inclined to insert trimeters in the text of the anapaests, but eventually decided not to do this in his 1986 OCT-edition. ${ }^{39}$ An important contribution of Zwierlein's study is the observation that the distribution of the pauses is not random

"I shall confine myself [...] to passages which are unquestionably in dimeters. [...] It is necessary to study only those dimeters whose colometry is sure. Such lines will need to meet the following qualifications:

1. no disagreement between $\mathrm{E}$ and $\mathrm{A}$ as to colometry;

2. no hiatus or brevis in longo at midline;

3. no violation of the principle of sense-correspondence;

4. no possibility of being part of a trimeter."

The author doesn't specify whether these dimeters are to be considered cola or periods, but he presumably assumes the latter.

${ }^{38}$ These criteria are spelled out in detail in Fitch (1987, 16-18).

${ }^{39}$ Zwierlein (1984, 183):

"Es ist nun sehr aufschlußreich zu verfolgen, wie man [...] das klare Indiz der Hss, daß neben der dimetrischen und monometrischen Abteilung auch trimetrische anzusetzen ist, beharrlich ignoriert: das Dogma von der dimetrischen Struktur des Anapästes wirkte so stark, daß Richter - der sich doch in beachtlicher Weise vom Diktat der Hss gelöst hatte - den entscheidenden Schritt zur Anerkennung trimetrischer Verseinheiten nicht zu tun vermochte."

Compare also the discussion of the Apocolocyntosis fragment in Zwierlein (1984, 191-192). For a justification for not printing trimeters in the OCT edition, see Zwierlein (1986, vi). 
(Zwierlein 1984, 182-202). A detailed study reveals that the attested instances of hiatus and/or breuis in longo mostly coincide with strong syntactic boundaries. According to Zwierlein (1984: 194), the majority of the pauses have a text-articulating function ("gliedernde Funktion"). In section 5.1.3, I will come back to this important point.

\subsection{To sum up}

Modern editors either try to remain faithful to the manuscripts (especially Leo) or they (fundamentally) change the colometry of the manuscripts (Richter, Zwierlein and Fitch). Nobody characterizes Seneca's anapaests as systemic. Furthermore, all scholars except for Müller presuppose that anapaestic dimeters exist.

In section 4, I will make a brief excursus: I will discuss anapaests that appear in Greek and (early and late) Latin literature. The discussion of the Greek marching anapaests will be of particular importance. After this, I will return to Seneca's anapaests in section 5, where I will answer the two questions formulated at the end of section 2, concerning the external and internal structure of Seneca's anapaestic odes. Section 5 also contains a critical evaluation of the Richter-Fitch approach.

\section{Anapaests in classical literature: a typology}

The main aim of this section is to set up a typology of anapaestic poems found in the classical literature in terms of the system developed in section 2 and summarized in Table 2. I will show that Greek and Latin anapaests come in three kinds. First, they can be systemic without an intermediate level of analysis in between the single metron and the entire system; second, they can be systemic with an additional articulation $\kappa \alpha \tau \grave{\alpha} \kappa \hat{\omega} \lambda \mathrm{\nu}$, and third, they can be built

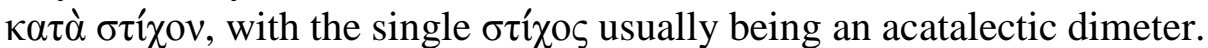

As outlined in section 2, the two audible clues that allow us to correctly distinguish the different types are (i) the presence and frequency of pauses (as signalled by hiatus, breuis in longo and/or catalexis) and (ii) the presence and location of caesurae. The former criterion allows us to determine whether a given passage is systemic or not, whereas the latter serves as a diagnostic to tell whether a poem is built $\kappa \alpha \tau \dot{\alpha} \kappa \hat{\omega} \lambda \mathrm{ov}$ or not.

\subsection{Greek anapaests ${ }^{40}$}

\subsubsection{Recited anapaests in the Attic dramas}

Recited anapaests ${ }^{41}$ are very frequently found in the Attic tragedies, especially in the parodus of the chorus. They appear in long sequences with a caesura after almost each metron. ${ }^{42}$ Hiatus and breuis in longo in between two metra are rare. ${ }^{43}$ As an example, I give the famous opening lines of the parodus of Aeschylus' Agamemnon (11. 40-47, text and colometry from Page 1972). The fragment consists of 14 metra, the last two of which constitute a paroemiac (a catalectic anapaestic dimeter):

(8)

$$
\begin{aligned}
& u \cup-u \cup-1 \cup u-\quad u-1
\end{aligned}
$$

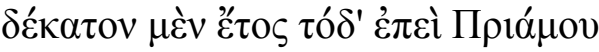

$$
\begin{aligned}
& \cup \cup-\cup \cup-1 \\
& \mu \varepsilon^{\prime} \gamma \alpha \varsigma \dot{\alpha} \nu \tau \tau^{\prime} \delta 1 \kappa \circ \varsigma \\
& \cup \cup-\cup-\mid-\cup \cup--1
\end{aligned}
$$

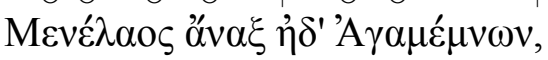

\footnotetext{
${ }^{40}$ For a detailed overview of anapaests in Ancient Greek literature, see Raabe (1912).

${ }^{41}$ The main differences between recited anapaests and their sung counterparts are listed in West $(1982,121)$.

${ }^{42}$ See Korzeniewski (1968, 88 n. 19) for a list of exceptions.

${ }^{43}$ Compare Korzeniewski $(1968,89)$ and West (1982b, 283 n. 11).
} 


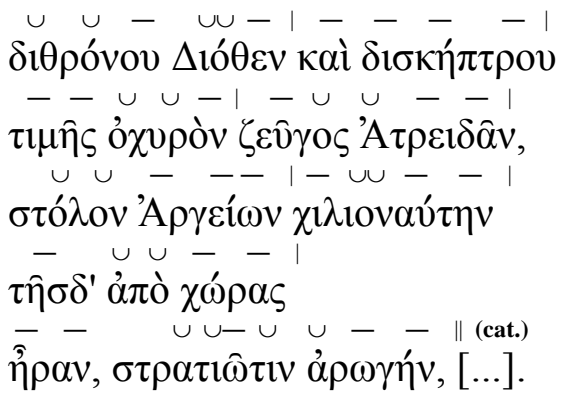

'This is the tenth year since lord Menelaos, Priam's great adversary, and with him Agamemnon, together the strong pair of Atreus' sons, two kings and two scepters bygrace of Zeus, left from this land with a fleet of one thousand ships of Argos, an army to fight for their cause.'

The fragment is given here with the traditional colometry as attested in the manuscripts. This colometry is adopted by most modern scholars and editors for this and all other recited anapaestic odes: the dimeter serves as the basic colon, and when a given period consists of an odd number of metra, one monometer appears at some point in the structure. ${ }^{44}$

An alternative analysis is put forward by von Wilamowitz-Möllendorf $(1910,129)$ and (1921, 113, 367), and is systematically pursued in West (1977). These authors are reluctant to acknowledge the existence of any metrical entity larger than the single anapaestic metron and smaller than the period. They prefer to treat the long sequences of metra as $\sigma v \sigma \tau \eta \dot{\mu} \mu \tau \alpha \dot{\varepsilon} \xi$ ó $\mu$ oí $\omega v$, structurally essentially identical to the well-known $\pi v^{\prime} \gamma \eta{ }^{45}$ The following passage formulates this view rather eloquently (emphasis mine, non-capitalization in original): ${ }^{46}$

"man mag denken, daß die später ganz feststehende praxis schon damals galt, die endlosen reihen von trochäischen iambischen anapästischen metra nach dimetern abzuteilen, soweit nicht eine ungerade summe eine abweichung forderte. denn die praktischen rücksichten empfehlen diese schreibart allein, die in anapästen ziemlich die länge des trimeters: da $\beta$ unsere metriker von dimetern reden, zeigt nur, wie sehr sie mit den augen messen. die dichter rechnen nicht mit dimetern: erst als die buchpraxis eine buchmetrik erzeugt hat, in der kaiserzeit, gibt es welche."

The most convincing empirical argument for this view is offered by older papyri, where no division into dimeters is made (West 1977, $101 \mathrm{n}$. 4). One such papyrus is P. Hib. 1.24(a), which contains part of the parodus of Euripides' Iphigenia in Tauris (11. 174-191). ${ }^{47}$ When we compare the way in which this passage is normally presented in a modern text edition $((9 \mathrm{a})$, from Diggle's (1981) OCT edition) with the papyrus fragment ((9b), from Grenfell and Hunt (1906)), it becomes clear that there is no line-to-line correspondence. Rather, in the older document, a single line (systematically) contains more than two anapaestic metra:

\footnotetext{
${ }^{44}$ See among others Maas $(1962,50)$ and Koster (1962, 151-157). Dale (1948, 48-49) on the 'occasional monometer': "Within the period occasional monometers occur among the dimeters, and as metron-diaeresis is so regular we are sometimes aware only of having an odd number of metra to set down, the particular metron selected for isolation being a matter of taste."

${ }^{45}$ See also Patzer (1983) for the use of the technical term $\pi v i$ yo $\varsigma$ in a 'non-comical' sense.

${ }^{46}$ von Wilamowitz-Möllendorf (1910, 129). This view is adopted by among others Drexler (1950), Mette (1959) and Nesselrath (1990). Thus Drexler (1950, 365, emphasis mine): "[...] hier [...] wird particula von particula durch Wortschluss abgesetzt, niemals aber entsteht aus den Teilen ein Ganzes, sondern nur eine Reihe von beliebiger Länge", and Nesselrath (1990, 269): "eine [...] Schreibkonvention".

${ }^{47}$ In the same footnote, West also mentions two other fragments from El Hibeh (viz. P. Hib. 1.25 and 2.179 i, 11. 4-18(?)) where a similar of lack of colon division can be observed. Compare Kannicht (1976, 126) on the "Metrum und Bauform" of the latter fragment: "halblyrische Anapäste, nach der Schreibgewohnheit des 3.Jh.

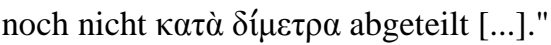


(9)

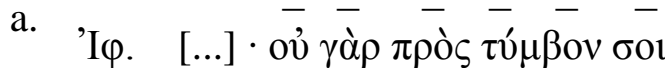

$-\quad-\quad-1-\cup \cup--$

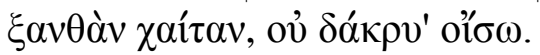

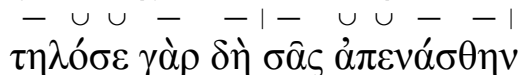

$u \cup-u \cup-1-u \cup-u \cup$

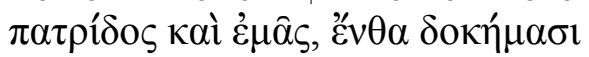

- - - - ।- - -\| (cat.)

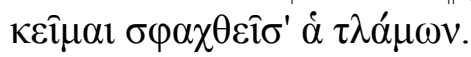

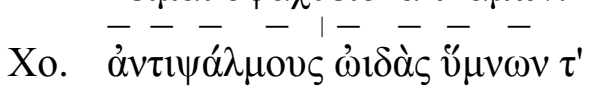

$\cup \cup--\quad-1-\bar{u} \cup-\bar{c}$

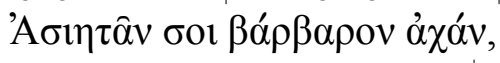

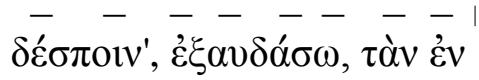

- _ $\quad-\quad-\mid \cup u-u \cup-1$

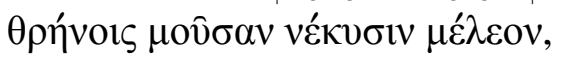

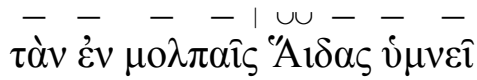

$\cup \cup---1$

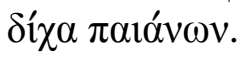

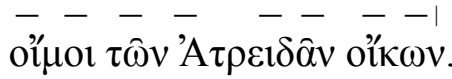

$\overline{-}-\overline{-} \quad-\quad-\quad \bar{\prime} \quad-\|$ (cat.)

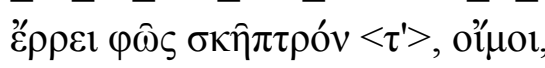

$\pi \alpha \tau \rho i ́ \omega v$ ớк $\omega v$.

( $\cup-\quad---\quad-\quad-1$

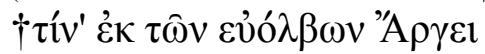

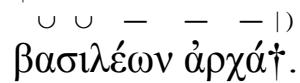

$-\quad-\quad-\quad-\quad-\quad-\|$ (cat.)

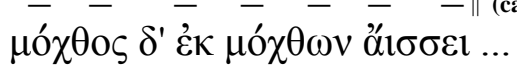

b.

$$
\begin{aligned}
& ] \alpha \text {. [ } \\
& \tau \eta \lambda \mathrm{o}] \theta_{\mathrm{l}} \gamma \alpha \rho \rho[ \\
& \varepsilon] \mu \alpha S_{[}[ \\
& \sigma \varphi \alpha \chi \theta \varepsilon 1] \sigma \underline{\alpha} \alpha \alpha \lambda[\alpha \mu \omega v \\
& v \mu \nu] \mathrm{o} v \tau \varepsilon \mathrm{A}[\sigma \eta \tau \tau \nu \\
& \alpha \chi] \alpha v \delta[\varepsilon \sigma \pi \mathrm{g} v \alpha \alpha \\
& \theta \rho \eta v o 1], s \mu \mathrm{ov}[\sigma \alpha v \\
& \mu \mathrm{o}] \lambda \pi \alpha 1 \varsigma \mathrm{A}[1 \delta \alpha \varsigma \\
& \pi \alpha 1 \alpha v \omega] v \text { or } \mu[\mathrm{ol}] \tau[\omega \nu \\
& \varphi] \omega \varsigma \sigma \kappa \eta \pi[\tau \rho \omega v \\
& \varepsilon v] \mathrm{o} \lambda \beta \omega v[ \\
& \mu \mathrm{o} \chi \theta \omega] \varphi \delta \varepsilon \varepsilon \gamma \mu[\mathrm{o} \chi \theta \mathrm{o} \varsigma \alpha 1 \sigma \sigma \varepsilon \mathrm{l} \\
& 174 \\
& 175 \\
& 176
\end{aligned}
$$

'For I will not bring auburn hair or tears to your tomb: far am I removed from your and my homeland, where people think I lay slaughtered, poor wretched one. // I shall answer you with responding songs, with the barbarian sound of Asian hymns, mistress, the sad music for the dead, mixed with laments, songs that Hades chants, different from paeans. Alas, the house of the Atreids! Gone is the light and the sceptre, alas, of the ancestral house. ... from the prosperous kings in Argos ... Hardship after hardship rushes on.'

Only in later papyri does the familiar dimeter colometry appears: the author attributes this to the influence of Alexandrian scholars like Aristophanes of Byzantion.

West goes on to refute a number of arguments favouring a dimeter colometry, put forward by among others Dale (1948, 47-68, especially 47-50). His strategy is always the same: he shows that all arguments in favour of dimeters can also be used to prove the existence of trimeters. For instance, many scholars have considered the (relatively rare) cases where two metra are united through verbal synaphy (i.e. cases where an expected caesura between two metra is absent) to be an indication that anapaestic dimeters are indeed real. However, by the same reasoning, Ar. Vesp. 753 would then have to be called a trimeter:

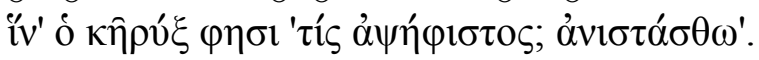

'Where the herald says: 'Who hasn't voted? Please stand up'.'

Additional evidence comes from testimonia of ancient grammarians: West (1977, 89-90) refers to Hephaestion (Enchiridion ed. Consbruch 1971, 70) and Diomedes (cf. section 5.3 below). One can also mention the following passage from Terentianus Maurus (De Metris 1512-1517, GLK 6, 370), in which the phenomenon of synaphy is discussed. Interestingly, the 


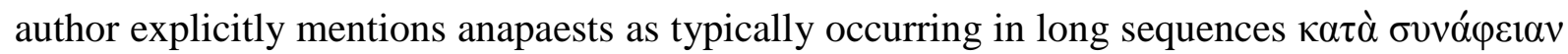
(emphasis mine):

(11)

metron autem

non uersibus istud numero aut pedum coartant,

sed continuo carmine quia pedes gemelli

urgent breuibus tot numero iugando longas,

1515

idcirco uocari uoluerunt ovvá $\varphi \varepsilon i \alpha v$.

anapaestica fiunt itidem per $\sigma v v \alpha ́ \varphi \varepsilon l \alpha v$.

uersus et non minus inde comparatur,

qui saepe pedes tres habeat, uel ille plures,

catalectica quos syllaba terminat frequenter,

1520

solet integer anapaestus et in fine locari.

'However, they don't confine this metre by means of verses or a fixed number of feet: for in an uninterrupted poem, paired feet succeed each other by combining long syllables with an equal number of short ones. For this reason, they chose to call this 'synaphy'. Anapaestic odes are also characterized by synaphy. A verse can be made in this manner as well: it often has three feet, or even more, which are frequently closed off by a syllable forming a catalexis, but a complete anapaest can also be placed at the end.'

At the end of his discussion, West (1977, 93-94) reaches the following conclusion:

"There was no regular colon-division inherent in the metre. [...] What I am suggesting, then, is that anapaestic dimeters are real, but a stylistic rather than a metrical phenomenon. Not only monometers but also trimeters and longer measures have an equal right to recognition beside them."

In his 1990 edition of Aeschylus, he puts this line of reasoning to practice. The first part of the parodus of the Agamemnon thus appears with trimeter units alongside dimeters:

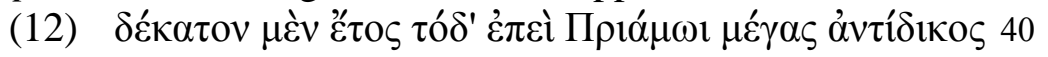

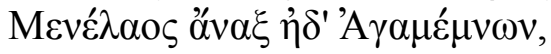

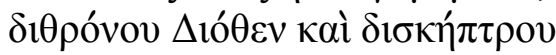

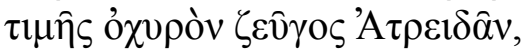

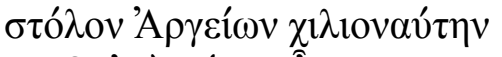

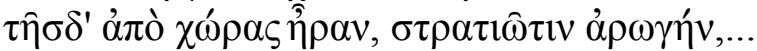

Earlier, Wilamowitz' student Mette $(1959,1963)$ had gone even further: in his edition of the fragments of Aeschylus, a colon division in (some) anapaestic passages was dispensed with altogether. ${ }^{48}$ Instead, the editor introduced diacritics to mark caesurae (and thus most metron boundaries), but the text appears essentially like prose. Such is for instance the case in the fragment from the Prometheus liberatus quoted by Strabo (1.2.27) (Mette 1959, 117 (fr. 323)):

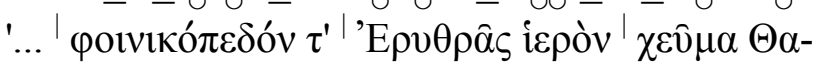

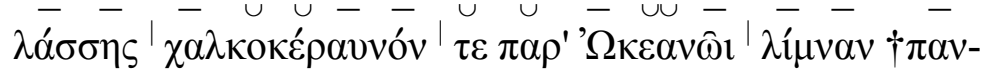

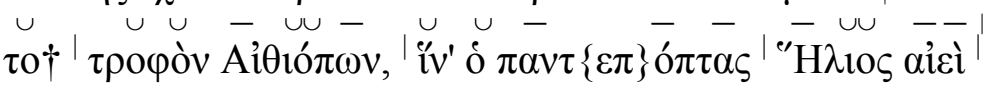

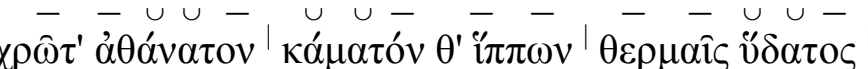

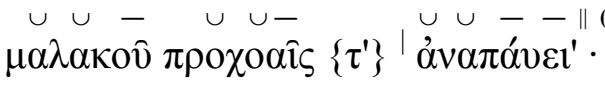

\footnotetext{
${ }^{48}$ This decision failed to raise much enthusiasm. Matthiessen (1966, 129): "Bei den Anapästen [...] verzichten wir nur ungern auf das gewohnte Schriftbild der abgesetzten Zeilen."
} 
'[...] the sacred stream of the red-bottomed Erythrean Sea, and the bronze-gleaming lake by the ocean, generously feeding the Aethiopians, where all-seeing Helius always refreshes his immortal body and the weariness of his steeds with warm outpourings of soft water.'

Elsewhere (Mette 1959, 176 (end of fr. 474, from the Dictyulci)), the editor does actually set apart dimeter units ${ }^{49}$ (presumably to highlight the lyric character of the anapaests, cf. the regular omission of caesurae), but only by means of additional diacritics (viz. a double straight line). Words are shifted to a new line only when they are at the beginning of a new period (1. 2), or simply when the words on a previous line have reached the right edge of the page (1l. 1 and 3):

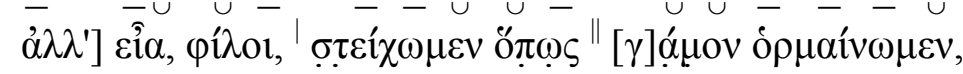

$$
\begin{aligned}
& \cup-u \cup-\quad-\cup \cup{ }_{-}-u^{\prime} \dot{u}_{-}-\| \text {(cat.) }
\end{aligned}
$$

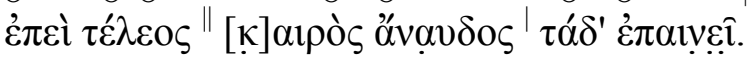

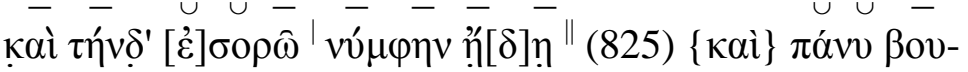

$$
\begin{aligned}
& \cup \cup-\quad-\cup \cup-\cup \cup-\cup \cup-\cup \cup--\| \text { (cat.) }
\end{aligned}
$$

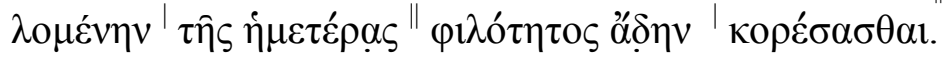

'But come now, dear friends, let us set out to get the wedding started: the time is right for it, and tacitly approves of it. And there I can see the bride, already very eager to fully enjoy our love.'

\subsubsection{Later developments}

In the later stages of Greek literature, a double evolution takes place: on the one hand, the acatalectic dimeter appears as an independent colon (and sometimes even as an independent period), and on the other hand, the $\pi v i$ i os-structure of the Attic dramas is still attested. I discuss and illustrate both patterns in turn.

4.1.2.1 Genuine acatalectic anapaestic dimeters Acatalectic anapaestic dimeters occur as an independent colon (and perhaps even as an independent period) from the end of the fifth century onwards. Lyric anapaests in the tragedies of Euripides are a point in case: the poet frequently omits the caesura in the middle of the colon, whereas the one at the end is always realized. The fragment in (15) (Eur. Ion 180-183), which is almost entirely spondaic, is probably systemic, but this is not absolutely certain:

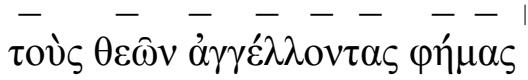

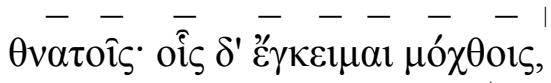

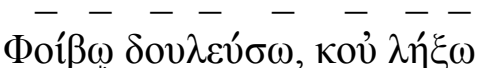

$$
\begin{aligned}
& -\quad-\quad-\cup \cup-\|_{\text {(cat.) }}
\end{aligned}
$$

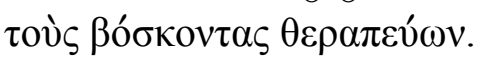

' ... those who convey the words of the gods to the mortals. But I shall serve Phoebus by fulfilling my duties, and I will not cease to honour those who feed me.'

In the imperial period, there is the following poem from Lucian's Podagra (Macleod 1967, $336,11.129-137)$. The even number of metra and the hiatus at the end of line 130 seem to indicate that the poem consists of dimeter- $\sigma \tau$ í 0 , although this cannot be claimed with full confidence:

\footnotetext{
${ }^{49}$ Thus not quite "with the individual metra marked off but with no further division before the catalexis", as West $(1977,89)$ puts it.
} 
'The air be still and windless, and every gouty man be silent. Lo, the goddess fond of bed strides to her altar, supported by a staff. Be welcome, most gentle of all the gods, approach, blessing all your disciples with your shiny smile. Release them all from their sufferings, in these days of spring.'

Finally, there is one outstanding piece of evidence that proves that anapaestic dimeters could be used as an independent colon. Three successive dimeters are attested in a poem known as the Ara Besantini. ${ }^{50}$ The full dimeters are given in (17). Since there is no interlinear hiatus or breuis in longo, it cannot be assessed whether the lines in question constitute independent periods or not. Now crucially, the entire poem is an acrostichon, which shows unambiguously that we are dealing with dimeters. If one reads the first letter of each line from top to bottom,

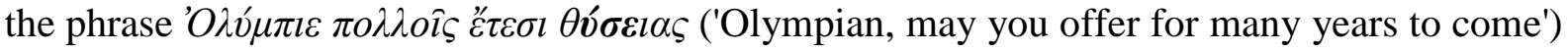
appears, with the contribution of the anapaestic lines highlighted in boldface.

$$
\begin{aligned}
& \text { 'Y }
\end{aligned}
$$

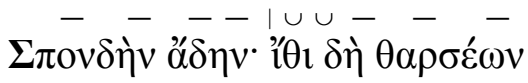

$$
\begin{aligned}
& \cup \cup--1 \cup \cup-\cup \cup-1
\end{aligned}
$$

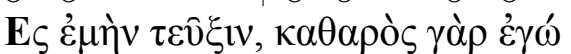

'... an abundant offering, much sweeter than the one of the Hymettiads. Come to me without fear, for I am pure...'

4.1.2.2 Systems without cola From the first century onwards, we find long sequences of anapaestic metra, with or without catalexis at the end. Most likely, these structures cannot be subdivided into units bigger than the single metron but smaller than the period. They are $\sigma v \sigma \tau \eta \dot{\mu} \mu \tau \alpha \dot{\varepsilon} \xi \dot{o} \mu \operatorname{ii}^{\prime} \omega v$, structurally akin to Aristophanean $\pi v^{\prime} \gamma \eta$. Some particularly striking examples are found in the Middle (and New) Comedy, in a total of 19 fragments. ${ }^{51}$ The longest fragment comes from the poet Mnesimachus (fr. 4 Kock, 4 PCG): there we find one period with uninterrupted synaphy consisting of 119 anapaestic metra and one paroemiac. As an example I give a fragment from Ephippus, which is a catalogue of different kinds of fish

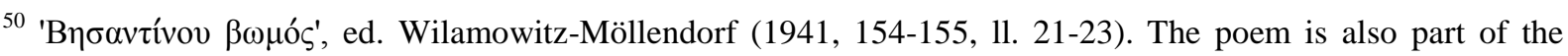
Anthologia Palatina (Anth. Pal. 15.25).

${ }^{51}$ Nesselrath (1990, 267-280) lists a total of 18 fragments, with one additional fragment from Menander: Antiphanes fr. 90, 91, 110, 130, 131 PCG; Ephippus fr. 1, 12, 13, 19 PCG; Eubulus fr. 63, 77 PCG; Anaxandrides fr. 28, 42 PCG; Epicrates fr. 10 PCG; Mnesimachus fr. 4 PCG; Philetaerus fr. 10 PCG; Alexis fr. 167 PCG; Menander fr. 258 Körte-Thierfelder.
} 
(Ephippos fr. 12 Kock, 12 PCG; those species which cannot be identified with certainty are omitted in the translation):

(18)

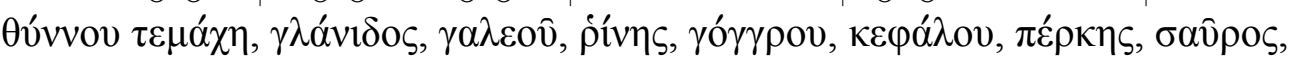

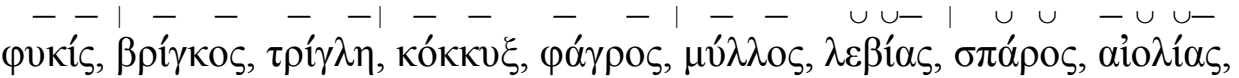

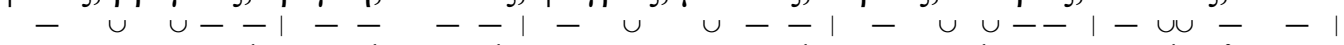

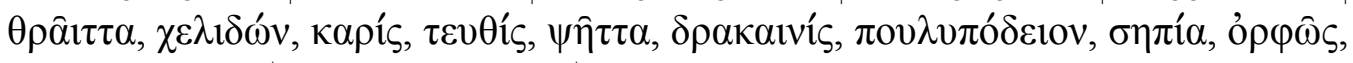

$$
\begin{aligned}
& \text { - u } \cup \cup-\mid \cup \cup-\quad-\quad-\text { । }
\end{aligned}
$$

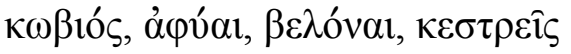

'Slices of tunny-fish, sheat-fish, dog-fish, shark, conger-eel, mullet, perch. And then horse-mackerel, wrasse, red mullet, piper, sea-bream, bream, speckled fish, flying fish, shrimps, squid, turbot, great weever, poulp, cuttle-fish, sea-perch, gudgeon, pipe-fish.'

\subsubsection{Summary}

To sum up, (acatalectic) Greek anapaests seem to come in three kinds. First, they can be construed as systems without a subdivision in cola (recited tragic anapaests and anapaestic $\pi v^{i} \gamma \eta$ from the New Comedy); second, they can appear as stichic dimeters (of which the fragment of the Ara Besantini is the clearest example), and third, they probably also can be both $\kappa \alpha \tau \grave{\alpha} \kappa \hat{\omega} \lambda o v$ and $\kappa \alpha \tau \grave{\alpha} \sigma v ́ \sigma \tau \eta \mu \alpha$ (cf. the example from Euripides in (15)).

\subsection{Three types of Latin anapaests}

I will now proceed to suggest that the three types of anapaestic poems identified above are also attested in the literature of the Romans. The systemic type without cola is found in the republican tragedy, and systems with cola are attested in Plautus. Purely stichic dimeters can be found in Boethius. I will postpone a discussion of Seneca's anapaests to section 5, concentrating for now on anapaests in the early and late Latin literature.

\subsubsection{Systemic I: systems without cola}

In the tragedies of the republican era, anapaests are found in the works of Accius and Pacuvius. In modern text editions, we usually read them as dimeters. A nice example comes from Accius (from the Philocteta, cf. Dangel 1995, 149):

(19)

Inclute

$-\cup \cup \cup \cup-1--u \cup-1$

nomine celebri claroque potens

$-\cup \cup--1-\cup \cup--1$

pectore, Achiuis classibus auctor,

$\cup \cup-\bar{u} \cup-1-u \cup--1$

grauis Dardaniis gentibus ultor,

$--\cup \cup-1$

Laertiade!

'O renowned man, sprung from a small fatherland, mighty hero with a famous name and widely known courage, adviser of the Achaean fleet, relentless punisher of the people of Dardanus, son of Laertes.'

I would like to stress that it is not justified to claim that the p-alliteration in 1. 195 somehow unites the first 2 metra of the fragment, setting them apart from the rest and thus making them a dimeter. As indicated (in boldface), two more words starting with a $\mathrm{p}$ appear in the following lines, and an additional alliteration with the $/ \mathrm{k} /$-sound (underscored) stretches over 6 metra. To the extent that the surviving fragments allow for any generalizations, the anapaests of Accius and Pacuuius do not seem to differ structurally from recited anapaests in the works of Aeschylus, Sophocles and Euripides. 


\subsubsection{Systemic II: systems with cola}

A variant of the systemic structure discussed in the previous section is found in Plautus' comedies. The main reasons to assume that the anapaestic quaternarii in (20) are best analysed as cola are the following. On the one hand, the poet does not systematically place a caesura in between an odd and an even metron (there is no caesura in lines 23-25 and 28), but on the other hand, the end of each colon does systematically coincide with the end of a word (Plaut. Stich. 23-28):

(20)

Noui ego illum; ioculo istaec dicit,

$\cup \quad \cup \cup \cup-\cup \cup-\quad--1$

neque ille sibi mereat Persarum

montis qui esse aurei perhibentur, $\mathbf{B}$

$\cup \cup-\cup \cup-:--\cup \cup-1$

$\cup \cup-\cup \cup-i \cup \cup---1$

tamen si faciat, minime irasci

$\cup \cup u \cup-u \cup-u \cup-\|$ (cat.)

decet, neque id immerito eueniet.

'I know him: he is making a joke. Not even if he gained those Persians mountains, who are said to be of gold, would he do what you are afraid of. Even if he did, there is no reason to be angry, and it wouldn't happen undeserved.'

Hiatus and breuis in longo, as in line 25, do occur in Plautus, but since they are relatively rare, it seems safe to conclude that not each quaternarius is an independent period. The existence of the quaternarius as a colon in a larger system is proven by those cases where the last element of the quaternarius is realized by two short syllables, as in Plautus Rudens 961:

quid inde aequom est dari mihi? dimidium

uolo ut dicas. // immo hercle etiam amplius,

$-\quad u \cup-u v-\ldots-$ -

nam nisi dat, domino dicundum

- $u \cup \quad u \cup-u \cup-\cup \cup-$ ।

censeo. // tuo consilio faciam.

'What is my fair share of it? I want you to say half. // Well, I'd say even more than half. And unless that's what he gives, I think we should tell the master // I'll follow your advice.' (= Plaut. Rud. 960-963) 52 $^{5}$

The two short syllables in bold face can only realize an elementum anceps, and not an indifferens. This is only possible inside a metrical system.

\subsubsection{Dimeters $\kappa \alpha \tau \grave{\alpha} \sigma \tau i ́ x o v$}

Late Latin anapaests are found in Boethius' De Consolatione Philosophiae. The 4 anapaestic poems $(1.5,3.2,4.6,5.3)$ exhibit considerable similarities with the ones composed by Seneca. ${ }^{53}$ Together, they consist of 322 metra, traditionally laid out as 160 dimeters and 2 monometers. Both monometers (1.5.36 and 5.3.31) are found at the end of a sentence; the last one is even the last metron of the entire poem. Both have the shape of an adoneus (DS), so it is perhaps not unlikely that they are intended to function as clausulae. The traditional colometry is probably correct. Furthermore, it is likely that the dimeters have a quite independent status. First, there are in total 32 pauses, ${ }^{54} 31$ of which occur at the end of a

\footnotetext{
${ }_{52}^{52}$ On this passage, see Boldrini (1984, 97-114).

${ }^{53}$ The most conspicuous difference is that Boethius, contrary to Senecan practice, allows for dactyls in the second half of a metron.

${ }^{54} 32 / 322=9,94 \%$ (frequency of the pauses compared to the total number of anapaestic metra), or $31 / 160=$ $19,38 \%$ (assuming a dimeter colometry). See also the discussion and the values for the Senecan corpus in section 5.1.1.
} 
dimeter. In the fragment in (22), a dimeter appears in isolation, delimited by two breues in longo (Boeth. Cons. Phil. 4.6.25-29):

(22) $-\ldots--1-\cup \cup--1$

Isdem causis uere tepenti

Spirat florifer annus odores,

- $-u \cup-1-\cup \cup--1$

Aestas Cererem feruida siccat,

$\cup \cup-\quad-1 \cup \cup---1$

remeat pomis grauis autumnus, $\mathbf{B}$

$\cup-\quad-\cup \cup \mid-\cup \cup--1$

Hiemem defluus inrigat imber. B

$-\quad-\quad \cup \cup-1$

Haec temperies...

'By the same causes, the flowery year breaths odours in mild spring; scorching summer dries the corn, and then autumn returns, heavy with fruits. The falling rain drenches winter. This moderation...'

Second, there is evidence that Boethius treated the first half of the dimeter differently than the second half. The statistical tendencies observed by Fitch in a sample of the Senecan corpus (cf. section 3.3.3.2) appear much stronger in Boethius (low frequency of SS in the second metron, compared to a high frequency of DS in the same position):

\begin{tabular}{|c|c|c|}
\cline { 2 - 3 } \multicolumn{1}{c|}{} & m 1 & m 2 \\
\hline DS & $17(10,63 \%)$ & $\underline{122(76,25 \%)}$ \\
\hline SA & $44(27,50 \%)$ & $12(7,50 \%)$ \\
\hline SS & $46(28,75 \%)$ & $2(1,25 \%)$ \\
\hline AA & $18(11,25 \%)$ & $9(5,63 \%)$ \\
\hline AS & $25(15,63 \%)$ & $13(8,13 \%)$ \\
\hline DD & $4(2,50 \%)$ & $0(0 \%)$ \\
\hline SD & $4(2,50 \%)$ & $2(1,25 \%)$ \\
\hline AD & $2(1,25 \%)$ & $0(0 \%)$ \\
\hline
\end{tabular}

Table 8: Dimeter patterns in Boethius' anapaests.

The underscored values are particularly telling: it seems safe to conclude that we are dealing here with both genuine dimeter patterns and genuine dimeters.

\subsection{Intermediate conclusion}

To sum up, we can be fairly confident that in both Latin and Greek, acatalectic anapaests are construed in three structurally different ways. Furthermore, pauses (i.e. the phenomena they are signalled by) and caesurae have proven to be reliable diagnostics to tell apart these three different structures.

I now return to the main subject of this paper. I will propose that Seneca's anapaests can be analysed as systems without cola, and that pauses serve to mark syntactic boundaries. Less frequently, they are used as a stylistic device. Moreover, I will argue that the observed rhythmical patterns are real but not part of the metrical structure.

\section{A novel analysis of Seneca's anapaests}

The analysis is split up in two parts. First I discuss the external structure of Seneca's anapaests, addressing the question as to whether they are systemic or not (section 5.1). Next, I 
turn to their internal structure, investigating whether on top of the obvious $\kappa \alpha \tau \grave{\alpha} \mu \varepsilon^{\prime} \tau \rho \mathrm{v}$ articulation, an additional division $\kappa \alpha \tau \grave{\alpha} \kappa \hat{\omega} \lambda$ ov should be postulated or not (section 5.2).

\subsection{External structure: stichic or systemic?}

\subsubsection{Frequency of the pauses}

For an overview of the number of pauses per play and per anapaestic passage I refer to Table 3 above. What I am interested in in this first section is the relative frequency of the pauses, say the average distance in between two interruptions of the metrical synaphy. However, quantifying this is not straightforward. Recall that there is no consensus about the exact colometry of the anapaests: by this token, we can also not be sure about the exact number of structural units with which the total number of pauses has to be compared. But let us try to offer an approximation.

Roughly speaking, there are two possible ways of counting: either we assume a monometer theory à la Müller, or we follow the communis opino and consider the dimeter to be the basic structural unit. In the former scenario, calculations are easy, since the totality of both comparanda is well known, namely 78 pauses and 1986 metra for the genuine Senecan anapaests (the Apocolocyntosis fragment included), and 152 pauses and 3384 metra in the entire corpus. Things are more difficult in the second scenario, since it is hard to determine how many dimeters one has to assume. What I will do is calculate the frequency of the pauses in the 'maximally dimetrical scenario', by just dividing the total number of metra in the genuine and total corpus (which both happen to be even) by two. This yields a total of 993 and 1692 dimeters respectively. The results are the following. In the first, 'monometric', scenario, there is a pause after 3,93\% of all the anapaestic metra of the genuine plays; the percentage is $4,49 \%$ for the entire corpus. If we assume dimeters, the figures are of course higher (the exact double in fact), since the same amount of pauses is compared to only half the number of structural units. I calculated $7,85 \%$ for the genuine plays and $8,98 \%$ for all ten of them (bearing in mind that these figures represent the most generous estimate possible).

How low these figures (under both scenarios) actually are becomes clear if we make a comparison with iambic trimeters, which are indubitably stichic. Note that iambs are very

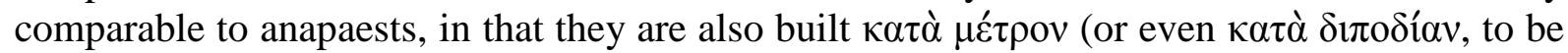
more precise). Moreover, in both anapaests and iambs, on the basis of 'internal responsion', the last element of a period is expected to be realized by a long syllable. However, interlinear hiatus and/or breuis in longo are significantly more frequent in iambic trimeters than in the anapaests: 


\begin{tabular}{|l|c|c|c|}
\hline \multicolumn{1}{|c|}{ play } & $\begin{array}{c}\text { \# of } \\
\text { trimeters }\end{array}$ & $\begin{array}{c}\text { interlinear } \\
\text { B and/or } \mathbf{H}\end{array}$ & percentage \\
\hline Hercules $\boldsymbol{F}$. & $1048(5)$ & 274 & $26,27 \%$ \\
\hline Troades & $919(6)$ & 239 & $26,18 \%$ \\
\hline Phoenissae & $664(1)$ & 150 & $22,62 \%$ \\
\hline Medea & $683(7)$ & 172 & $25,44 \%$ \\
\hline Phaedra & $951(6)$ & 251 & $26,57 \%$ \\
\hline Oedipus & $741(7)$ & 183 & $24,93 \%$ \\
\hline Agamemnon & $710(7)$ & 199 & $28,31 \%$ \\
\hline Thyestes & $767(6)$ & 211 & $27,73 \%$ \\
\hline Hercules O. & $1413(10)$ & 353 & $25,16 \%$ \\
\hline Octauia & $599(7)$ & 138 & $23,31 \%$ \\
\hline \multicolumn{1}{|r|}{ Total: } & $8495(62)$ & 2170 & $25,73 \%$ \\
\hline
\end{tabular}

Table 9: Frequency of interlinear hiatus and/or breuis in longo in Senecan iambic trimeters

If one assumes that Seneca's anapaests are stichic just as his iambic trimeters (regardless of the size of the anapaestic $\sigma \tau^{\prime}$ íol assumed), the highly different frequencies of pauses in these two contexts are unexpected. We can take this to be a first indication that Seneca's anapaests are not stichic.

\subsubsection{The realization of the final syllable}

Further comparison with strictly stichic periods in Seneca again suggests that there is no such

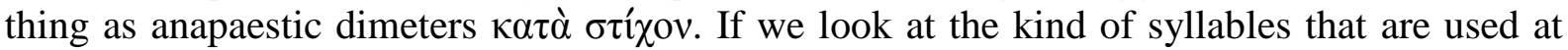
the end of the alleged dimeters, we see that closed syllables with long vocalism are strongly preferred, whereas open syllables with a short vowel are dispreferred:

\begin{tabular}{|c|c|c|}
\hline & \multicolumn{2}{|c|}{$\begin{array}{l}301 \text { 'certain' dimeters } \\
\text { (Fitch 1987): }\end{array}$} \\
\hline $\begin{array}{l}\text { Nature of the } \\
\text { final syllable }\end{array}$ & $\begin{array}{l}\text { \# of attes- } \\
\text { tations }\end{array}$ & $\%$ \\
\hline open, short vocalism & 3 & $\underline{1,00 \%}$ \\
\hline closed, short vocalism & 85 & $28,24 \%$ \\
\hline open, long vocalism & 66 & $21,93 \%$ \\
\hline closed, long vocalism & 127 & $\underline{42,19 \%}$ \\
\hline uncertain: $-\mathbf{0}$, sibi, ubi,... & 20 & $6,64 \%$ \\
\hline
\end{tabular}

Table 10: Nature of the last syllable of the dimeters in the sample in Fitch (1987).

In stichic periods on the other hand, the most common last syllable is a closed one with short vocalism. Moreover, open syllables with a short vowel are much more common than in the anapaests:

\footnotetext{
${ }^{55}$ Between brackets: number of iambic passages, and thus of the number of trimeters that end a passage. These trimeters were not taken into consideration for counting the number of interlinear 'pauses'.
} 


\begin{tabular}{|c|c|c|c|c|}
\cline { 2 - 5 } \multicolumn{1}{c|}{} & \multicolumn{2}{c|}{$\begin{array}{c}\text { Oedipus } \mathbf{7 5 7} \\
\text { trimeters) }\end{array}$} & \multicolumn{2}{c|}{$\begin{array}{c}\text { Phoenissae (664 } \\
\text { trimeters) }\end{array}$} \\
\hline $\begin{array}{c}\text { Nature of the } \\
\text { final syllable }\end{array}$ & $\begin{array}{c}\text { \# of at- } \\
\text { testations }\end{array}$ & $\%$ & $\begin{array}{c}\text { \# of at- } \\
\text { testations }\end{array}$ & $\%$ \\
\hline open, short vocalism & 55 & $7,27 \%$ & 71 & $10,69 \%$ \\
\hline closed, short vocalism & 354 & $46,76 \%$ & 292 & $43,98 \%$ \\
\hline open, long vocalism & 76 & $10,04 \%$ & 66 & $9,94 \%$ \\
\hline closed, long vocalism & 228 & $30,12 \%$ & 183 & $27,56 \%$ \\
\hline not certain: -o\#, sibi, ubi,... & 44 & $5,81 \%$ & 52 & $7,83 \%$ \\
\hline
\end{tabular}

Table 11: Realization of the elementum indifferens in Senecan iambic trimeters.

\begin{tabular}{|c|c|c|c|c|}
\cline { 2 - 5 } \multicolumn{1}{c|}{} & \multicolumn{2}{c|}{$\begin{array}{c}\text { Senecan asclepiadei } \\
\text { (312) }\end{array}$} & \multicolumn{2}{c|}{$\begin{array}{c}\text { Senecan glyconei } \\
\text { (237) }\end{array}$} \\
\hline $\begin{array}{c}\text { Nature of the } \\
\text { final syllable }\end{array}$ & $\begin{array}{c}\text { \# of at- } \\
\text { testations }\end{array}$ & $\%$ & $\begin{array}{c}\text { \# of at- } \\
\text { testations }\end{array}$ & $\%$ \\
\hline open, short vocalism & 28 & $8,97 \%$ & 11 & $4,64 \%$ \\
\hline closed, short vocalism & 141 & $\underline{45,19 \%}$ & 99 & $41,77 \%$ \\
\hline open, long vocalism & 41 & $13,14 \%$ & 32 & $13,50 \%$ \\
\hline closed, long vocalism & 78 & $25,00 \%$ & 75 & $31,65 \%$ \\
\hline not certain: -o\#, sibi, ubi,... & 24 & $7,69 \%$ & 20 & $8,44 \%$ \\
\hline
\end{tabular}

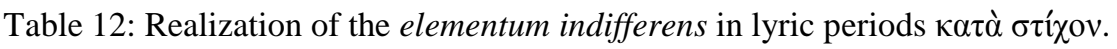

These facts also show that there are significant differences between the anapaests and purely stichic periods like iambic trimeters. More specifically, the very low frequency of open syllables with a short vowel at the end of a(n alleged) anapaestic dimeter can be seen as a strategy to avoid a disruption of the metrical synaphy. Note that open syllables with short vocalism have to be followed by a (relatively rare) syllable with a consonant cluster in its onset in order for the synaphy not to be interrupted. On the other hand, the poet seems to have had a strong preference for ending 'dimeters' with a closed syllable with long vocalism. Again,

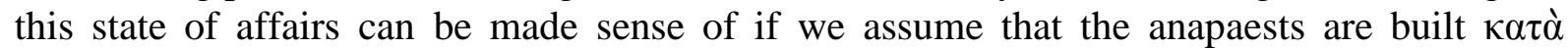
бuvá $\varphi \varepsilon 1 \alpha v$, as such a syllable guarantees continuous synaphy, irrespective of the properties of the following word. However, this strong preference remains totally mysterious if we assume

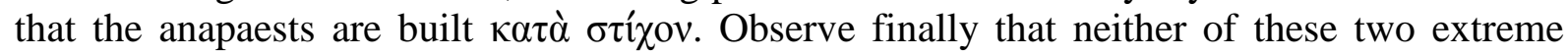
tendencies can be observed in the case of the genuinely stichic periods: in all 4 of the samples that I looked at, the type of syllable most frequently attested at the end of a period is a closed syllable with a short vowel, which can be considered a fairly neutral type of syllable (in terms of its propensity to give rise to interruptions of the synaphy).

But what about the pauses that actually are attested in the anapaests?

\subsubsection{Distribution and function of the pauses}

As was mentioned above, Zwierlein showed that pauses in between two anapaestic metra tend to coincide with syntactic boundaries. ${ }^{56}$ If one assumes a three-way distinction, with heavy syntactic breaks (end of a sentence), light syntactic breaks (boundary between a main and a subordinate clause, or between two coordinated clauses) and no syntactic break at all, it appears that over half of the pauses coincide with a strong syntactic break, and that only a minority occurs in the middle of a syntactic unit (less than 10\%):

\footnotetext{
${ }^{56}$ Zwierlein (1984) (see also section 3.3.4).
} 


\begin{tabular}{|c|c|c|c|c|}
\hline & \multirow{2}{*}{$\begin{array}{c}\text { Seneca }^{57} \\
(1986)\end{array}$} & \multicolumn{2}{|c|}{ pseudo-Seneca } & \multirow{2}{*}{$\begin{array}{l}\text { Total } \\
\text { (3324) }\end{array}$} \\
\hline & & $\begin{array}{c}\text { Her. } O . \\
(601)\end{array}$ & $\begin{array}{c}\text { Oct. } \\
\text { (737) }\end{array}$ & \\
\hline Heavy break: end of a sentence & 51 & 9 & 28 & $88(57,89 \%)$ \\
\hline Light break: para- or hypotaxis & 21 & 7 & 22 & $50(32,89 \%)$ \\
\hline No break & 6 & 2 & 6 & $14(9,21 \%)$ \\
\hline Total & 78 & 18 & 56 & 152 \\
\hline
\end{tabular}

Table 13: Distribution of the pauses in (pseudo-)Senecan anapaests.

Between brackets in the first row: total number of metra.

Below, I give a number of examples of each type of syntactic environment in which a metrical pause can occur:

i. Sentence final pauses: Phaedra 30-31 (23) and Phaedra 52-54 (24):

(23)

uulnere multo iam notus aper. B

$-\quad-\quad-1 \cup \cup-\cup \cup-1$

At uos laxas canibus tacitis

$-u \cup--1$

mittite habenas...

'a boar, renowned for many a wound. But you men, give free rein to the silent dogs.'

(24)

$-\quad--1---$

tu iam uictor curuo solues

$$
\begin{aligned}
& -\cup \cup--\| \\
& \text { uiscera cultro. } \mathbf{H}
\end{aligned}
$$

$\cup \cup-u \cup-\mid-\cup \cup--1$

Ades en comiti, diua uirago,...

'Upon victory, you will break loose the entrails with your curving knife. Come divine heroine, stand by your companion.'

ii. Coordination or subordination: Agamemnon 322-325 (34) and Troades 723-725 (35):

(25)

Arcus uictor, pace relata,

Phoebe, relaxa $\mathbf{H}$

$\cup \cup-\cup \cup-|\cup \cup---|$

umeroque graues leuibus telis

$$
-\cup u--1
$$

pone pharetras

'Once peace restored, loosen your bow, victorious Phoebus, and take off your shoulder the quiver, heavy with light arrows.'

(26)

qui perfracto limine Ditis

$--\quad--\mid \cup \cup-\cup \cup-\|$

caecum retro patefecit iter, $\mathbf{B}$

$-\quad--1--\cup \cup-1$

hostis parui uictus lacrimis

'who, after shattering the threshold of Dis, opened up the dark way back, persuaded by the tears of his small foe.'

iii. no syntactic break: Agamemnon 85-86 (27) and Thyestes 948-949 (28):

\footnotetext{
${ }^{57}$ the 60 metra from the Apocolocyntosis included.
} 
$--\quad-1-u \cup-\cup \|$

quas in planum quaelibet hora $\mathbf{B}$

$\cup \cup--1$

tulit ex alto.

'[homes], that any hour can bring down from high above to the ground.'

(28)

$-\quad-\cup \cup-1-\cup \cup--\|$

pingui madidus crinis amomo $\mathbf{H}$

$--\cup \cup-1 \cup \cup---1$

inter subitos stetit horrores

'My hair, soaked with thick unguent, stands upright through these sudden fears.'

Zwierlein (1984, 182-202; see also section 3.3.4) suggested that the pauses are not random licences, but that they serve a specific function. According to Zwierlein, they either serve to break up long stretches of anapaestic metra into smaller chunks, or alternatively, they have a more stylistic function: they set apart a (mostly small) number of metra from the previous ones, so that the former are somewhat emphasized. A parallel with this last function can perhaps be found in the Greek tragic anapaests. According to West (1982b, 283 n. 11), hiatus and breuis in longo in anapaests mainly occur in 'emotionally charged contexts'. The following fragment from the Thyestes (875-882), with 3 pauses shortly after one another, suggests that something similar might be true in some of the Senecan cases:

$$
\begin{aligned}
& \text { Nos e tanto uisi populo } \\
& -\quad \cup \cup-1 \quad----1 \\
& \text { digni, premeret quos euerso } \\
& -\cup \cup-\quad-\| \\
& \text { cardine mundus? B } \\
& \text { in nos aetas ultima uenit? } \mathbf{B} \\
& -\quad--1-\cup \quad \cup--1 \\
& \text { o nos dura sorte creatos, } \\
& -\quad-\cup \cup-1--\quad \cup \cup-1 \\
& \text { seu perdidimus solem miseri, } \\
& -\quad-\cup \cup-\| \\
& \text { siue expulimus! B }
\end{aligned}
$$

Abeant questus, discede timor:...

'Have we, out of so many people, been judged worthy to be crushed by the weight of heaven, its axis overturned. Has the end of times come upon us? Alas, we were born with a cruel fate, whether we lost or chased away the sun through our misfortune. But let complaints go away, let fear retreat.'

\subsubsection{Intermediate conclusion I}

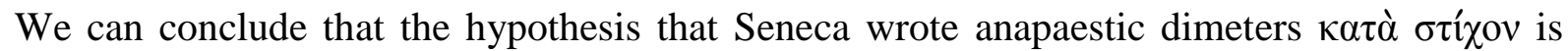
sufficiently falsified. There is robust evidence that even the most prototypical dimeters (in the Fitchean sense) do not behave as genuine stichic periods. ${ }^{58}$ Furthermore, it seems plausible that Seneca used pauses as a stylistic device.

I now turn to the second question, namely the one concerning the internal structure of the anapaestic periods. I will argue against a $\kappa \alpha \tau \grave{\alpha} \kappa \hat{\omega} \lambda \mathrm{ov}$-analysis for Senecan anapaests.

\footnotetext{
${ }^{58}$ The initial error was in my opinion made by Leo, who made the statistical exception (occurrence of metrical

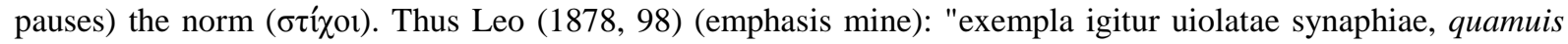
pauca sint, sufficiunt tamen ad demonstrandum non seueram sibi Senecam conectendorum anapaestorum normam scripsisse."
} 


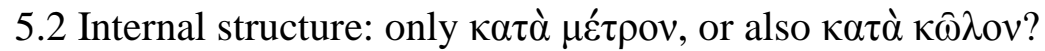

5.2.1 More on 'aurality': rhythmical patterns as an audible structuring element?

Recall from the discussion in section 4 that the presence or absence of caesurae is an important diagnostic for the presence or absence of colon-units inside a metrical period which is built $\kappa \alpha \tau \grave{\alpha} \mu \varepsilon \dot{\tau} \tau \rho o v$. In the case at hand, systematic placement of a caesura after each even metron coupled with regular omission of the caesura after an odd metron would suggest a structure with dimeters. As mentioned in the introduction (section 1.1), it so happens that every single anapaestic metron in the Senecan corpus is followed by a caesura. The weak conclusion that one could draw from this observation is that the evidence from caesurae does not support a theory that postulates dimeter cola. Importantly however, it also doesn't falsify such a theory. A stronger conclusion would be to interpret this observation as evidence that Seneca took care not to provide the listener with any clues that could have helped to identify dimeters as seperate units. In any event, the behaviour of caesurae does not provide a decisive argument in favour of or against any theory.

The question now arises whether there was any other element that could have informed the hearer about the existence of dimeter cola. The obvious candidate are the rhythmical patterns identified by Richter and Fitch. Although I am not aware of any parallel case where such patterns are the sole auditory clue that justify a $\kappa \alpha \tau \grave{\alpha} \kappa \hat{\omega} \lambda \mathrm{ov}$ colometry, it is definitely not a priori implausible that rhythmical preferences can fulfill a structuring function. For instance, the well-documented tendency for the third metron of the Senecan iambic trimeter to be more strongly regulated than the first two (Boldrini 1999, 104) can be considered an auditory clue that signals the end of a metrical unit. ${ }^{59}$ In the next section, I will investigate how strong a case can be made for postulating rhythmical patterns as a structuring element in the particalur case of Seneca's anapaests.

\subsubsection{Metrical patterns: a critique of Fitch (1987)}

Before evaluating the merits of the principle of sense-correspondence as a guiding principle in establishing a colometry for Seneca's anapaests, let me first point out a general problem with Fitch's approach (and by extension, with many other approaches). Recall that Fitch presupposes the reality of dimeter and monometer units without any further argument (cf. section 3.3.3.2). At a methodological level, this is highly problematic. Given the very similar case of the Greek marching anapaests, it is not at all clear whether the assumption that dimeters exist should be granted the status of a certain premise on which a further argument can be built with full confidence. Consider in this respect the following comment from Sperber and Wilson $\left(1995^{2}, 111\right)$ :

"When all the premises actually used in the derivation of a particular conclusion are certain, the conclusion is also certain. When all the premises but one are certain, the conclusion inherits the strength of the less-than-certain premise. When more than one premise is less than certain, then the conclusion is weaker than the weakest premise."

As a result, any conclusion reached by someone who considers the existence of dimeter units a given is bound to be conditional (or provisional, pending the discovery of a knock down argument in favour of the existence of dimeters).

But let us assume for the sake of the argument that dimeters do exist (keeping in mind that we cannot be $100 \%$ sure about this), and that we have to determine which anapaestic metra are part of a dimeter, which ones aren't, and why. Let us then evaluate the merits of the

\footnotetext{
${ }^{59}$ On the 'demarcating' function of some metrical constraints, see also Fortson $(2008,99)$. Note however that in the case ot the iambic trimeter the preferred rhythmical pattern for the third metron is not the only element that signals the end of the metrical unit (which is in this case is a period rather than a colon). Regular pauses do so too, and presumably more strongly so.
} 
system proposed in the 1987 monograph. Recall that the main claim of Richter and Fitch is that since Seneca had a predilection to map self-contained syntactic units to certain rhythmical patterns, rhythmical patterns can be used by the contemporary philologist as a diagnostic to establish a colometry. But can this line of reasoning really be maintained in its strong form? How strong a law is the Kongruenzgesetz/principle of sense-correspondence?

5.2.2.1 Sentence end at the middle of a metron First of all, a fully generalized one-to-one mapping of syntactic and metrical structure is not possible, given the existence of strong syntactic breaks in the middle of a metron ${ }^{60}$, as in Hercules Furens 1083-1085 (viz. in 1084B):

(30)

En fusus humi saeua feroci

$-u \cup--1-\quad u \quad-\quad-\quad$ ।

corde uolutat somnia: nondum est

$----\mid \cup \cup-\cup \cup-1$

tanti pestis superata mali.

'And look, as he lies on the ground, cruel dreams are in his fierce heart: not yet has the curse of such a great crime been overcome.'

Another example is Thyestes 875-877: the metron in 876A contains the boundary between a main clause (nos e tanto uisi populo) and a dependent relative clause (with preposed finite verb, premeret quos euerso cardine mundus). From these and similar passages, we can conclude that the Kongruenzgesetz is at best a violable constraint that allows for occasional exceptions.

5.2.2.2 Size and properties of the sample in Fitch (1987) Second, recall that the conclusions reached by Fitch are not based on an analysis of the totality of the Senecan anapaests. Importantly, his sample of 'prototypical' dimeters only represents less than a third of the (genuinely Senecan) anapaestic material, namely 602 metra out of a total 1979 in the 2002-04 LCL editions $(602 / 1979=30,42 \%) .{ }^{61}$ This is problematic for (at least) two reasons.

The first reason concerns the way in which Fitch's sample was assembled. In statistics, the totality of tokens of a given phenomenon that one studies is called the population. Since in many cases this population is quite big, the statistician often only investigates a part of the population, which is then called a sample. However, as any basic introductory textbook on data analysis can teach us, one should take great care in assembling this sample. A relevant quote in this respect is the following (Gries 2009, 24-26, italics in original):

"[...] it is important that you choose your sample such that it is representative and balanced with respect to the population to which you wish to generalize. Here, I call a sample representative when the different parts of the population are reflected in the sample, and I call a sample balanced when the sizes of the parts in the population are reflected in the sample. [...] If you do not do that, then the whole study may well fail because you may be unable to generalize from whatever you find in your sample to the population. One important rule in this connection is to choose the elements that enter into your sample randomly, to randomize. [...] However you do it, randomization is one of the most important principles of data collection."

In other words, what one has to avoid at all costs is that the sample be biased. Fitch did exactly the opposite. ${ }^{62}$ This has of course non-trivial consequences for the validity of his conclusions.

\footnotetext{
${ }^{60}$ On sense breaks in the middle of a metron in Greek tragic anapaests, see West (1977, 93 and 101 n. 12).

${ }^{61}$ A similar objection is raised by Zwierlein (1990, 694 n. 7).

${ }^{62}$ In argumentation theory, this strategy is known as the 'fallacy of biased statistics' (see for instance Tindale 2007, 161).
} 
Second, singling out $30 \%$ of the anapaests as the only clear dimeters amounts to saying that the remaining $70 \%$ are not clear dimeters, at least not syntactically. Furthermore, since the Kongruenzgesetz implies that rhythmical patterns are mapped onto self-contained senseunits, it is not at all clear how one could apply this principle in a case where no sense-units can be identified. But Fitch does so. In his Loeb editions, he prints 846 dimeters in the genuine tragedies. 545 (i.e. 846 minus 301) of these dimeters do not coincide with clear sense-units as defined in the 1987 monograph. Moreover, at least a subset of the 545 nonprototypical dimeters coincides with something which is clearly not a sense-unit, under no definition of the concept. Consider again the fragment from the Phaedra that was also quoted in the introduction. This time it is given with Fitch's colometry (Phaedra 5-8):

(31) quae Thriasiis uallibus amnis

5

rapida currens uerberat unda

scandite colles

semper canos niue Riphaea.

In this passage, the two metra in line 5, quae Thriasiis uallibus amnis 'which (acc.) the river in Thria's valley', clearly do not constitute a self-contained unit, neither conceptually, nor stylistically, nor syntactically. So why should they be printed as a dimeter? And where is the Kongruenz? I can see the metrical pattern (SA-DS, i.e. the most common pattern according to Fitch's findings (cf. Table 7 above)), but where is the sense-unit it is supposed to correspond with, given the Kongruenzgesetz/principle of sense-correspondence (and assuming that it takes two to correspond)?

To conlude, it is very questionable whether conclusions reached on the basis of such a limited amount of material (30\%) can be generalized to the whole corpus (100\%). After all, the rest of the material was not included in the sample exactly because it does not contain any clear syntactic dimeters: so why would it contain any metrical dimeters? More generally, it is quite clear that Fitch's methodology is fundamentally flawed: it is simply not correct to assume that a carefully assembled sample can be taken to be representative for an entire population. By the same token, it is not correct to extrapolate conclusions that are valid for a specialized niche to the entire population.

5.2.2.3 Strength of the observed tendencies A different but related problem concerns the strength of the tendencies that were observed in the 'clear dimeters'. The figures are repeated here for convenience (see also section 3.3.3):

\begin{tabular}{|c|c|c|}
\cline { 2 - 3 } \multicolumn{1}{c|}{} & m 1 & m 2 \\
\hline DS & $43(\underline{14,3 \%})$ & $155(\underline{51,5 \%)}$ \\
\hline SA & $106(35,2 \%)$ & $73(24,3 \%)$ \\
\hline SS & $72(\underline{23,9 \%)}$ & $10(\underline{3,3 \%})$ \\
\hline AA & $35(11,6 \%)$ & $41(13,6 \%)$ \\
\hline AS & $45(15,0 \%)$ & $22(7,3 \%)$ \\
\hline
\end{tabular}

Table 6: Metrical patterns in 301 anapaestic dimeters: percentages.

Upon closer inspection, it seems that the observed tendencies are indeed real, but they are only tendencies. Moreover, they are only mild tendencies, much less strong than similar patterns in Boethius (cf. Table 8 in section 4.2.3 above). In any event, they are nothing compared to for instance the absolute absence of verbal synaphy between two anapaestic metra in the Senecan corpus, or to the strong restrictions that Seneca imposed on the possible realization of the third metron of the iambic trimeter (Strzelecki 1938; Boldrini 1999, 104). The latter two constraints can rightfully be called 'laws'. 
5.2.2.4 No Kongruenzgesetz for monometers? A final - and perhaps most devastating problem are the 426 monometers in Fitch's edition. In recent text editions, a gradual proliferation of monometers can be observed. The relevant quantitative data are given in Table 14 (an extended version of Table 4):

\begin{tabular}{|c|c|c|c|c|c|c|c|}
\hline nr. & passage & \# metra & \multicolumn{5}{|c|}{ \# monometers } \\
\hline & & & $\mathbf{A}$ & $\mathbf{E}$ & $\begin{array}{c}\text { BT } \\
1902\end{array}$ & $\begin{array}{l}\text { OCT } \\
1986\end{array}$ & $\begin{array}{c}\text { LCL } \\
2002-04\end{array}$ \\
\hline 1. & Her. F. 125-201 & 155 & 2 & 0 & 9 & 9 & 13 \\
\hline 2. & Her. F. 1054-137 & 165 & 1 & 1 & 10 & 14 & 21 \\
\hline 3. & Tro. $67-163$ & 188 & 3 & 1 & 20 & 22 & 30 \\
\hline 4. & Tro. $705-35$ & 61 & 0 & 1 & 1 & 3 & 13 \\
\hline 5. & Med.301-79 & 155 & 3 & 3 & 7 & 9 & 18 \\
\hline 6. & Med. 787-842 & 109 & 5 & 3 & 9 & 9 & 15 \\
\hline 7. & Phaed. 1-84 & 157 & 0 & 8 & 16 & 18 & 26 \\
\hline 8. & Phaed. 325-57 & 64 & 0 & 1 & 5 & 7 & 9 \\
\hline 9. & Phaed.959-88 & 59 & 3 & 3 & 3 & 3 & 5 \\
\hline 10. & Phaed. 1123-7 & 10 & 0 & 0 & 0 & 0 & 0 \\
\hline 11. & Phaed. 1132-48 & 31 & 2 & 2 & 4 & 3 & 6 \\
\hline 12. & Oed. 154-201 & 94 & 2 & 2 & 4 & 10 & 18 \\
\hline 13. & Oed. 432-44 & 25 & 0 & 1 & 1 & 3 & 3 \\
\hline 14. & Oed.738-63 & 51 & 1 & 1 & 1 & 1 & 3 \\
\hline 15. & Oed.980-97 & 33 & 1 & 1 & 1 & 3 & 3 \\
\hline 16. & Ag. 57-107 & 98 & 4 & 4 & 4 & 9 & 14 \\
\hline 17. & Ag. 310-87 & 147 & 1 & 49 & 49 & 37 & 43 \\
\hline 18. & Ag. 637-58 & 40 & 0 & 2 & 4 & 4 & 6 \\
\hline 19. & Ag. 664-92 & 58 & 0 & 0 & 0 & 4 & 8 \\
\hline 20. & Thy. 789-884 & 187 & 3 & 0 & 9 & 13 & 21 \\
\hline 21. & Thy. 920-69 & 99 & 3 & 1 & 3 & 5 & 12 \\
\hline 22. & Her. O. 173-232 & 118 & 1 & 5 & 3 & 9 & 11 \\
\hline 23. & Her. O. 583-705 & 242 & 2 & 2 & 2 & 8 & 14 \\
\hline 24. & Her. O. 1151-60 & 20 & 0 & 0 & 0 & 0 & 0 \\
\hline 25. & Her. O. 1207-17 & 22 & 0 & 0 & 0 & 0 & 0 \\
\hline 26. & Her. O. $1279-89$ & 22 & 0 & 0 & 0 & 0 & 2 \\
\hline 27. & Her. O. 1863-939 & 150 & 2 & 8 & 8 & 10 & 12 \\
\hline 28. & Her. O. 1983-96 & 27 & 1 & 1 & 1 & 3 & 5 \\
\hline 29. & Oct. 1-33 & 62 & 4 & 1 & 4 & 2 & 6 \\
\hline 30. & Oct. 57-99 & 82 & 8 & I & 6 & 12 & 12 \\
\hline 31. & Oct. 201-21 & 40 & 2 & I & 2 & 2 & 3 \\
\hline 32. & Oct. 273-376 & 198 & 0 & I & 18 & 17 & 26 \\
\hline 33. & Oct. 646-89 & 84 & 4 & 1 & 6 & 8 & 12 \\
\hline 34. & Oct. $762-79$ & 36 & 0 & 1 & 0 & 0 & 0 \\
\hline 35. & Oct. 806-19 & 28 & 2 & I & 4 & 4 & 4 \\
\hline 36. & Oct. $877-982$ & 207 & 2 & l & 12 & 18 & 32 \\
\hline & Total : & 3324 & 62 & 100 & 226 & 279 & 426 \\
\hline
\end{tabular}

Table 14: Absolute frequency of anapaestic monometers in manuscripts and text editions. 
As can be seen, the number of monometers in the latest LCL editions is significantly higher than in the two previous authoritative editions of the entire corpus, which themselves contain many more monometers than the manuscripts. Importantly, the 426 monometers in Fitch's edition do not together form a homogeneous class. There clearly is no such thing as a preferred or statistically predominant rhythmical pattern for monometers, analogous to the dimeter patterns. As shown in Tables 15 and 16, Fitch's monometers take more or less the same shape as any given anapaestic metron in the Senecan corpus:

\begin{tabular}{|c|c|c|c|c|}
\cline { 2 - 5 } \multicolumn{1}{c|}{} & \multicolumn{2}{c|}{ \# of attestations } & \multicolumn{2}{c|}{$\%$} \\
Sen. & Ps.-Sen. & Sen. & Ps.-Sen. \\
\hline DS & 672 & 458 & $33,84 \%$ & $34,23 \%$ \\
\hline SA & 562 & 422 & $28,30 \%$ & $31,54 \%$ \\
\hline SS & 282 & 194 & $14,20 \%$ & $14,50 \%$ \\
\hline AA & 249 & 153 & $12,54 \%$ & $11,43 \%$ \\
\hline AS & 212 & 107 & $10,67 \%$ & $8,00 \%$ \\
\hline DA & 1 & 4 & $0,05 \%$ & $0,30 \%$ \\
\hline Tot. & $\mathbf{1 9 8 6}$ & $\mathbf{1 3 3 8}$ & \multicolumn{2}{c}{} \\
\cline { 1 - 5 } & & &
\end{tabular}

Table 15: Metrical profile of the totality of the anapaestic metra in the (pseudo-) Senecan tragic corpus.

\begin{tabular}{|c|c|c|c|c|}
\cline { 2 - 5 } \multicolumn{1}{c|}{} & \multicolumn{2}{c}{ \# of monometers } & \multicolumn{2}{c|}{ \% } \\
\multicolumn{1}{c|}{ Sen. } & Ps.-Sen. & Sen. & Ps.-Sen. \\
\hline DS & 75 & 52 & $28,74 \%$ & $31,52 \%$ \\
\hline SA & 80 & 66 & $30,65 \%$ & $40,00 \%$ \\
\hline SS & 33 & 16 & $12,64 \%$ & $9,70 \%$ \\
\hline AA & 50 & 21 & $19,16 \%$ & $12,72 \%$ \\
\hline AS & 21 & 8 & $8,05 \%$ & $4,85 \%$ \\
\hline DA & 2 & 2 & $0,77 \%$ & $1,21 \%$ \\
\hline Tot. & 261 & 165 & \multicolumn{3}{c}{} \\
\cline { 1 - 5 } & & &
\end{tabular}

Table 16: Monometers in the edition of Fitch (2002-04).

In sum, the only thing Fitch's monometers seem to have in common is the fact that they don't fit in one of Fitch's dimeters. In other words, many of the added monometers are essentially just 'metrical junk'. But is there any principled reason why monometers should be exempt from Richter's Kongruenzgesetz or its Fitchean counterpart? It seems to me that there is no such reason. On the contrary, if one were to take the principle of sense-correspondence really seriously, then the system should also allow for trimeters and even bigger units, and only monometers that constitute an independent sense-unit, as Thyestes 986A (dolor an metus est? 'Is it pain or fear?'), should be kept as such.

Paradoxically, Fitch's treatment of anapaestic monometers thus implies a strong departure of a colometry based on sense correspondence, quite the opposite of what the author claims to aim for. Strings of words like tradat et omnes ('may bring and all', Her. F. 193A), furor insontem ('madness (nom.) innocent (acc.)', Her. F. 1098A), patriaeque fuit ('for his country was too', Tro. 129B) and optat et alto ('desires and in the high', Med. 327B), all (newly introduced) monometers in Fitch's edition, will never be sense units, by no stretch of anybody's imagination.

\subsubsection{Intermediate conclusion II}

We can conclude that once the entire anapaestic corpus is taken into account, the rhythmical patterns observed are not as general as proposed by Fitch: they constitute a tendency, not a 
law. I would therefore like to propose that below the level of the entire period, the single anapaestic metron is the largest metrical unit that can unambiguously be distinguished aurally, namely by virtue of the presence of a caesura after each one of them. In other words, the internal structure of the anapaestic periods in the Senecan corpus tragicum is only characterized by a subarticulation $\kappa \alpha \tau \dot{\alpha} \mu \varepsilon \dot{\tau} \tau \rho o v$, without any additional division $\kappa \alpha \tau \dot{\alpha} \kappa \hat{\omega} \lambda \sigma v$. Moreover, those dimeters that do obey the principle of sense-correspondence can only be granted the status of a stylistic phenomenon, if any. It will therefore come as no surprise that I fully share the criticism voiced by Wilson $(1990,193)$, in his review of Fitch's monograph: ${ }^{63}$

"Fitch is especially concerned with the visual arrangement of the lines of anapaestic verse on the page. But it is the ear rather than the eye that is perhaps the better judge of Latin verse. [...] How are line ends to be marked aurally? The 'almost incantatory' effect Fitch claims for Seneca's anapaestic odes will be independent of the visual arrangement of the lines."

\subsection{Magis rythmus quam metron}

One of the consequences of the analysis developed thus far is that Seneca's anapaests are very strictly regulated at the level of the single metron, whereas they are allowed to run in free course at the level of the period. I would like to submit that this yields a remarkable tension between two phenomena which are often discussed in the theoretical literature, viz. metre and rhythm. The following testimonium is particularly relevant in this respect (Diomedes, GLK 1, 512-513):

(32) Anapaesticum dimetrum fit incisione, cuius haec exempla sunt,

$$
\begin{aligned}
& \cup \cup-\cup \cup-1---\| \text { (cat.) } \\
& \text { agite o pelagi cursores, } \\
& \cup \cup \| \text { (cat.) } \\
& \text { cupidam in patriam portate. }
\end{aligned}
$$

sunt hic bini anapaesti aut qui recipi solent, in imo autem aut bacchius est, qui constat ex duabus longis et breui, aut molossus, qui constat ex tribus longis. alienum autem pedem metra nisi recipiant, modus non facile finitur et magis rythmus est quam metron.

'The anapaestic dimeter comes with a caesura, of which the following lines are examples: [...]. We have here each time two anapaests or the feet that can stand in their place. At the end however, there is a baccheus ${ }^{64}$, which consists of two long syllables and one short, or a molossus, which has three long syllables. If the [anapaestic] metra are not followed by a foot which is foreign to the anapaestic rhythm, it is not easy to round off the composition. In such a case, we are dealing with rhythm rather than with metre.'

Note first of all that the dimetrum anapaesticum referred to by Diomedes is the paroemiac, not the acatalectic dimeter. The grammarian goes on to discuss the way a period is best ended. He proposes that an unexpected 'check' in the rhythm is needed, namely a foot which is not found period-internally. If a period only (i.e. also at the end) consists of feet which are allowed inside an anapaestic period (anapaests, dactyls and spondees), a strong effect of continuity is created. This is exactly what happens in the case of Seneca's anapaests: they are

\footnotetext{
${ }^{63}$ A very similar point is made by Seva $(1977,151)$ (emphasis mine):

"Aquest error, de Leo i d'altres, s'origina en una concepció visual - falsa, doncs -, no auditiva, de la mètrica. En efecte: el paremíac, [...] es diferencia de la sèrie anterior [...]. Però això no s'esdevé en els monòmetres anapèstics senequians, que són absolutament idèntics en ritme als hemistiquis dels dímetres anteriors i, posat cas, dels posteriors [...]. Són, doncs, irreconeixibles com a finals a l'oüda."

${ }^{64} \mathrm{It}$ is more common to call the sequence - - - an antibaccheus. A baccheus (also sometimes spelled as 'bacchius') is the reverse image ( $\cup--)$, but terminological confusion is not uncommon.
} 
not regularly delimited by an audible end point. This leads Diomedes to characterize such structures as 'more rhythmical than metrical'. Now what exactly does this mean?

In the wake of Aristoxenus of Tarentum, many Greek and Roman grammarians made a principled distinction between rhythm (Gr. $\rho 0 \theta \mu$ ó, , Lat. rhythmus, rythmus or numerus) on

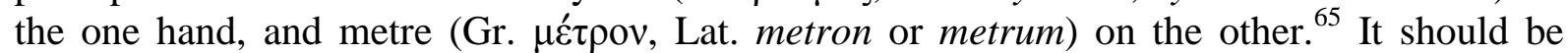
stressed that there is by no means an absolute consensus among ancient grammarians - nor among modern metricians or musicologists ${ }^{66}$ - about the exact definition of the two terms, nor about the relation between the two phenomena. Nevertheless, quite a number of ancient scholars have proposed that the main difference between metre and rhythm is exactly this contrast between boundedness and unboundedness. A clear formulation of this idea can be found in Quintilian (Inst. 9.4.50):

(44) Sunt et illa discrimina, quod rhythmis libera spatia, metris finita sunt; et his certae clausulae, illi quomodo coeperant currunt usque ad $\mu \varepsilon \tau \alpha \beta \mathrm{o} \eta \eta^{\prime} v$, id est transitum in aliud genus rhythmi.

'There are some other differences too: rhythms are not limited in space, whereas metres are finite. Metres end in fixed patterns, rhythms can go on and on just as they began until they reach a metabole, by which I mean a transition to another type of rhythm.'

This and other testimonia ${ }^{67}$ confirm the hypothesis that the anapaests in the Senecan tragedies are a kind of hybrid form in between rhythm and metre. Their metrical character is at its strongest at the lower echelons of the structural hierarchy (the single metron); at the higher structural level of the entire period, they are much freer and thus more akin to rhythm.

In the concluding section, I will elaborate more on the tension between rhythm and metre in the Senecan anapaestic poems. Before this, I will first address one remaining problematic issue (section 5.4), and I will try to reconstruct how the dimeter-colometry might have come into being (section 6).

\subsection{A remaining problem: the distribution of elisions}

In later work, Fitch adduces an additional piece of evidence in favour of his dimetercolometry (Fitch 2004b, 266-268). In his by now familiar sample of 301 dimeters, there are in total 59 elisions. 52 of those appear in the first metron, and only 7 in the second one. He states (p. 267): 'The aesthetic considerations behind the avoidance of second-metron elision are not immediately evident, but other metres reveal a comparable discrimination about where elision is permitted or avoided [note omitted].' In the omitted footnote, Fitch mentions asclepiads and iambic trimeters as some of these other metres. My countings reveal that in 312 Senecan

\footnotetext{
${ }^{65}$ Aristides Quintilianus (book I, Winnington-Ingram 31-35, 38-40) calls the scholars who make this distinction

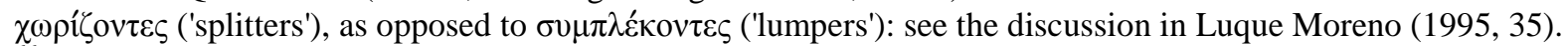

${ }^{66}$ See van Raalte (1986, 1-27) and Hasty (1997, 3-58) for two (fairly) recent overviews of the state-of-the-art in these two fields.

${ }^{67}$ E.g. Varro fr. 88 Goetz-Schoell (p. 218), apud Marium Victorinum, GLK 6.50.4:

(i) Metrum est compositio pedum ad certum finem deducta ... uel rhythmus modis finitus.

'Metre is a combination of feet leading to a fixed end point, or in other words, rhythm with limited length.' and Isid. Etym. I.39.1-3:

(ii) DE METRIS. Metra uocata, quia certis pedum mensuris atque spatiis terminantur, neque ultra dimensionem temporum constitutam procedunt. Mensura enim Graece $\mu \varepsilon ́ \tau \rho o v$ dicitur. Versus dicti ab eo, quod pedibus in ordine suo dispositi certo fine moderantur per articulos [...] Huic adhaeret rythmus, qui non est certo fine moderatus, sed tamen rationabiliter ordinatis pedibus currit.

'Metra are called the way they are, because they are delimited by the measures and sizes of feet, and they do not proceed beyond the fixed of time units. For 'measure' in Greek is called $\mu \varepsilon \tau^{\prime} \rho o v$. Verses got their name from the fact that they consist of feet, which occur in a specific order. Verses are subdivided in smaller units, and have a certain end point. Related to this is rhythm, which is not delimited by a fixed end point, but runs in a predictable way with ordered feet.'
} 
asclepiads, 13 elisions and 4 aphaereses appear before the middle caesura, and only 4 elisions are found after it. However, as to the iambic trimeters, figures presented by Soubiran (1966, 519,532 ) show that elision is equally frequent in the first half of a iambic trimeter as in the second half (in both cases there is elision at $8,8 \%$ of the intermots in the respective halfverses). ${ }^{68}$

In the light of the conclusions reached earlier the pattern observed might have to be rephrased in the following sense: on the basis of Fitch's countings, it seems to be the case that elisions in the anapaests tend to occur at the beginning of sense units (which his 301 'dimeters' indeed are), whereas they are avoided at the end of such units. I agree that the (aesthetic?) motivation behind this tendency is not clear and I remain agnostic as to the correct interpretation of the observed asymmetry.

\section{How did the dimeter-colometry come about?}

Before concluding this paper, I will very briefly address the question as to how the dimeterplus-occasional-monometer colometry ended up in the medieval manuscripts on which our present day text editions are based. To all likelihood, a number of factors can be held responsible for this state of affairs.

First, it is likely that the dimeter colometry was first introduced by Alexandrian scholars, as suggested by West (1977, 89 and 101 n. 4). It is well known that the Alexandrians made a similarly wrong analysis of the sapphic stanza, which they failed to analyse as one single period consisting of three cola. Horace (and Seneca in his wake) adopted the Alexandrian analysis: in their poems, a sapphic stanza consists of 4 independent periods (3

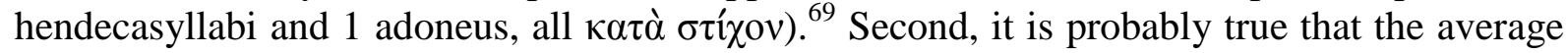
length of a sense-unit roughly coincides with an anapaestic dimeter: it might have been tempting for medieval scribes to turn this tendency into a generalization. Third, dimeters probably were the 'best fit' for the average column in a medieval codex: trimeters were inconveniently long, and systematically writing just one metron per line meant a loss of precious space. Fourth, the presence of metrical pauses might have raised the impression of a non-systemic structure. However, given the low rate and the totally irregular intervals at which the pauses occur, they do not justify a regular dimeter-colometry $a$ la Leo. Fifth, the tendency to conceive of two metra as one unit is probably also due to the existence of lyric anapaests (cf. section 4.1.2.1) and of paroemiacs, whose status as an independent colon is not disputed. ${ }^{70}$ Sixth, some ancient testimonia have in my opinion not been interpreted correctly by proponents of the dimeter-theory. A first relevant example comes from Marius Victorinus $\left(\right.$ GLK 6, 76.28-77.13) ${ }^{71}$ :

(33) Hoc loco dicam, cur, cum sint duae periodi seu stasima, ut quidam uocant, pari inter se coniugatione copulata, alterum uocatur anapaesticon, alterum dactylicon, cum aeque in

\footnotetext{
${ }^{68}$ Fitch's reference to Zwierlein (1984) is inaccurate: the latter only discusses elision affecting long vowels and diphthongs.

${ }^{69}$ Liberman (2005).

70 The paroemiac was a very old verse, especially popular for short proverbs, as witnessed by Hephaestion (Enchiridion ed. Consbruch 1971, 26):

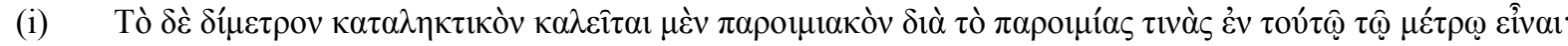

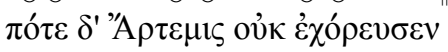

$$
\begin{aligned}
& \text { - }-\cup \cup-\cup \cup--\| \text { (cat.) }
\end{aligned}
$$

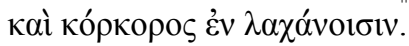$$
\cup \cup-\| \text { (cat.) }
$$

'The catalectic dimeter is called 'proverbial' because of the fact that some proverbs are in this metre: 'Artemis never didn't dance' 'and a tailor among kings' (lit. 'and a blue pimpernel in vegetables')'.

${ }^{71}$ The sentence in boldface is often quoted or paraphrased by modern scholars (see for instance Mantke 1957-58, 104).
} 
utraque cadant mixti dactylus et anapaestus. causa talis, quod anapaesticon melos binis pedibus amat sensum includere, ut apud Accium:

$$
\begin{aligned}
& -\cup \cup--1-\cup \cup \cup \cup-1 \\
& \text { inclyte, parua praedite patria } \\
& -\cup \cup \cup \cup-1--\cup \cup-1 \\
& \text { nomine celebri claroque potens } \\
& -\cup \cup \cup-1-1-\cup \cup--1 \\
& \text { pectore, Achiuis classibus auctor. }
\end{aligned}
$$

quae periodos circa sex uersatur dipodias. contra Pacuuius nouare propositum uolens noluit intra binos pedes, ut superius, finire sensum, sed secundum Euripidem dactylicum metrum, quod appelatur, induxit, ut mominis mutatio diuersitatem daret, huius modi stasimo seu periodo usus:

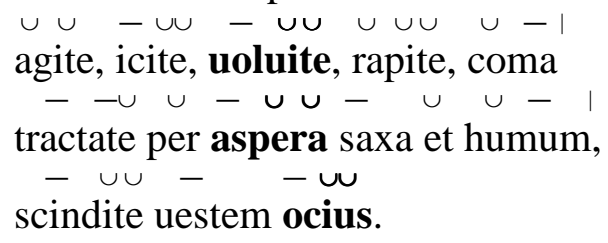

'Now I will explain why two periods - or stasima, as some people call them -, which are closely related to each other, are sometimes called anapaestic and sometimes dactylic, although both contain dactyls as well as anapaests. The reason for this is that an anapaestic song likes to have a word end after each two feet, as for example in Accius: [...]. This period stretches out over six dipodies. Pacuvius on the other hand, in his quest for innovation, did not want word end to occur after each two feet, as above, but following Euripides, he introduced a dactylic schema, to obtain a different pattern by changing the rhythm. He would write a stasimon or period of the following kind: [...].'

Note first of all that the fragment in (33) is taken from Marius Victorinus' chapter $D e$ anapaestico metro: both literary fragments he discusses are anapaestic, but only the first one is truly anapaestic. The second one is something like 'dactylic anapaestic', in a sense to be explained below. Observe furthermore that the Accius-fragment contains two enjambments: parua ... patria and claro ... pectore. This fact leads Zwierlein ${ }^{72}$ to understand the word pes in the sense of 'metron' (whence binis pedibus = binis dipodias = unum dimetrum). However, this interpretation cannot be defended. First, understanding pes as meaning metron is completely ad hoc, not in the least because the same author uses the word dipodia to denote a combination of two feet only a couple of lines later. Second, sense-units just do not coincide with metrical units in the quoted fragment: for instance, the sense-unit parua praedite patria consists of three feet, i.e. not a metrical unit in any sense. Moreover, in whatever way the colometry of the Accius-fragment is arranged, the single metron pectore, Achiuis will never form a sense-unit. sensus is in my opinion best understood as meaning 'word ${ }^{13}$, and binis pedibus sensum includere would mean that a single word is never spread over two dipodies. And this is exactly what happens in the Pacuvius-fragment. The middle caesura is absent, and the words occurring in the middle of the colon across the metron boundary all scan as dactyls, whence the 'dactylic' nature of this anapaestic period. ${ }^{74}$ To conclude, the phrase anapaesticon melos binis pedibus amat sensum includere does not offer any support for a colometry with the anapaestic dimeter as a basic unit. On the contrary, it seems to lend support to a theory which claims that the basic unit is the single monometer, à la Müller.

\footnotetext{
${ }^{72}$ Zwierlein (1984, 199): 'pes offensichtlich im Sinne unseres Begriffes metrum verwendet'.

${ }^{73}$ However, OLD (s.v. sensus, especially 9-10) does not give this as a possible interpretation.

${ }^{74}$ The same pattern as in the Pacuvian examples is found in Eur. Iph. T. 160:

(i) 
Second, some people have argued that the fact that the only extant locus where a Roman grammarian quotes a passage from Seneca's anapaests (viz. Med. 301) consists of two metra supports the theory that dimeter cola exist (see for instance Mantke 1957-58: 104). The relevant fragment is given in (34) (emphasis mine):

(34) Anapaesticus, qui ex pedibus anapaestis constat, [...] recepit pedes sui generis, de qua re supra diximus. anapaestus autem fit ex duabus breuibus et longa. Anapaesticum choricum habemus in Seneca, 'audax nimium qui freta primus'.

'An anapaestic verse, which is formed by anapaestic feet, can contain feet of its kin, which we discussed earlier. An anapaestic foot consists of two short syllables and one long. We have an example of a choral ode in Seneca: 'audax nimium qui freta primus'.

(= Diomedes, GLK 1, 511, 18-28)

However, it is not likely that Diomedes really wanted to quote an independent colon: he is talking about odes, not about verses. It may very well be the case that he just wanted to quote the first line of the ode, as it might have been written down in his fourth-century codex.

Finally, most of the times when the ancient grammarians talk about 'anapaestic dimeters', they refer to the paroemiac, as for instance in the testimonium of Marius Victorinus in (32): Anapaesticum dimetrum fit incisione eqs. The dimeters quoted in that fragment are both catalectic (i.e. paroemiacs), as are all the dimeters in Hephaestion's Enchiridion. I only found one ancient grammarian who explicitly mentions and illustrates the phenomenon of acatalectic anapaestic dimeters, namely Atilius Fortunatianus (ca. 300 C.E.(?); GLK 6, $285.23,297.21)$. This is of course not unexpected, since we know that the acatalectic dimeter was used as an independent $\kappa \hat{\omega} \lambda$ ov or $\sigma \tau i ́ \chi 0 \varsigma$ (in Plautus and Boethius respectively).

\section{Some thoughts on visual representation}

The only remaining issue then concerns the way in which the anapaests should (or could) be visually represented in a modern text edition. As pointed out above (section 2.2.1), this question is related to (and in the best case dependent on) a metrical analysis, but logically distinct from it. Also, the text editor's task to establish a colometry is always to some extent subjective, whereas a formal metrical analysis ideally involves as little subjective interpretation as possible. Here, I will only address two points: one cautionary remark about the difference between hyperbata and enjambments, and a second concerning the extent to which the structural properties of the anapaestic passages discussed above ('stylistic cola' (sense-units), and perhaps even pauses and caesurae) should be visualized or not.

First, let me point out that the practice of adding cola to the representation of a text which is not structurally built $\kappa \alpha \tau \alpha \grave{~} \kappa \hat{\omega} \lambda \mathrm{ov}$ might come at a cost. For most modern readers, a line is a line, and there is no such thing as synaphy between two lines. ${ }^{75}$ The result of adding a

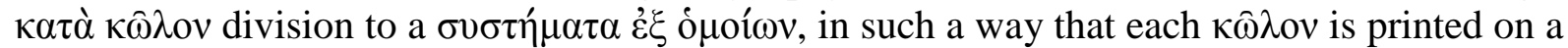
different line, is that many enjambments are introduced into the printed text in places where the original text only has a syntactically discontinuous constituent (or perhaps a right dislocated phrase). Consider for instance the following example from the Troades (158-160): (35a) shows Zwierlein's colometry, (35b) the one of Fitch. The first colometry features two enjambments, the second one, whereas the actual text has none. ${ }^{76}$

\footnotetext{
${ }^{75}$ In most modern metrical systems, long periods as in Greek and Latin lyric poetry are per definition absent, since long periods exist by virtue of the phenomenon of continuous metrical syllabification described in section 2.2.1, which is only possible in quantitative metrical systems.

${ }^{76}$ Fitch's text contains less enjambments than many other editions, given his concern to reorganize the text in such a way that the different parts of a discontinuous constituent appear one and the same line. However, the price he has to pay for this operation is the high number of unmotivated monometers (see section 5.2.2.4).
} 
'Now he wanders among the peaceful shadows of the Elysian forest, and blest among the pious spirits he searches Hector.'

Enjambments are usually considered a rather marked stylistic device: one could say that the stronger the metrical break in between the two relevant parts of the sentence (caesura, colon end, pause), the stronger the effect of the enjambment. ${ }^{77}$ However, one should not forget that for many modern readers, the difference qua strength between the three metrical breaks just mentioned is irrelevant: what counts is the end of a line, and any constituent split across it will be an enjambment. In my opinion, the reader's interpretation is at least to some extent influenced in quite an illegitimate way when the number of enjambments in a text is artificially increased by adding an ill-justified colon-division (all modern Seneca editions, the medieval manuscripts included).

A second issue is whether long stretches of anapaests should be subdivided into 'stylistic' cola, and perhaps also whether or not diacritics are needed to signal the presence of caesurae and pauses. In other words, do we want a colometry with monometers, dimeters, trimeters and perhaps even longer units (cf. Zwierlein 1984; West 1990), or a prose-like layout (with diacritics) as in Mette (1959)? Here I will only list some advantages and drawbacks of both options. The first option clearly seems the best way to come closer to the Richter/Fitch ideal to do justice to Seneca's predilection for 'sense correspondence' by typographically harmonizing syntax and metre. Note that subdividing the text into non-metrical subparts can be motivated independently: the newly created units seem very similar to so-called prose cola' identified in the literature since Fraenkel (1932-33). ${ }^{78}$ On the other hand, recall that syntactic and metrical constituents do not systematically coincide (see e.g. (30)), which precludes a one-to-one correspondence between form and meaning. Moreover, there is perhaps the disadvantage that cola are represented in the same way as stichich periods, but as this is standard practice in editions of for instance Greek lyric poetry, this is perhaps le moindre mal. One can imagine that on the whole, a West-style representation with nonmetrical cola would for many people be an acceptable solution. This is actually what Zwierlein (1984, 191-192) proposed for Seneca, and applied to anapaestic passage in the Apocolocyntosis. The beginning of the second strophe of the nenia on emperor Claudius (ll. 19-23) thus features one monometer and three consecutive trimeters:

$$
\begin{aligned}
& --\cup \cup-1 \\
& \text { Deflete uirum, } \\
& --\cup \cup-|\cup \cup-\cup \cup-|-\cup \cup--1 \\
& \text { quo non alius potuit citius discere causas } \\
& ---1---1--\cup \cup-1 \\
& \text { una tantum parte audita, saepe neutra. } \\
& \quad-\quad--|----|-\cup \cup--\mid
\end{aligned}
$$

\footnotetext{
${ }^{77}$ Observe that enjambment (defined as the spreading of syntactic material over two metrical cola or periods), and the (intended and/or perceived) stylistic effects associated with it are so to speak 'parasitic' on a fixed and well-defined metrical structure: the presence of the latter is a precondition for the former (cf. Fraenkel 1932, 200: "Fuge aber und Enjambement schliessen einander aus."). Under the present analysis, this condition is not met in Seneca's anapaests.

${ }^{78}$ See also Stinton (1977) and Habinek (1985). Prose-cola are perhaps to be equated to (longer) intonational phrases distinguished in the literature on prosodic phonology (Nespor and Vogel 20072; Hayes 1989).
} 
'Mourn the loss of the man, quicker than whom nobody could make up his mind about a case, by hearing only one party, often even neither! Which judge will now listen to lawsuits all year long?'

The alternative is to leave the task of parsing the text into sense units to the reader, and to indicate the boundaries of metrical units only by means of diacritics. Optionally, one could also indicate the presence of pauses. However, it is safe to say that although this approach seems the most correct from a purely metrical point of view, introducing diacritics in the way Mette did will presumably not be for everybody's taste.

One might also object that depriving a piece of poetry of structural units that do not fill an entire line essentially reduces poetry to prose. However, this reasoning contains a clear anachronism: the concept of line ('visually' defined) is a modern one, which only bears imperfect resemblance to its ancient predecessors, viz. auditorily defined metra, cola and periods (and combinations thereof). It seems ill-advised to sacrifice an inherent part of Seneca's composition only in order to comply with the expectation of present day readers to see poetry laid out in 'verses'. In the anapaests, synaphy is part and parcel of the poet's compositional technique and in my view, deserves to be brought to the attention of the modern reader.

\section{Conclusion}

On the basis of the evidence discussed in this paper, we can conclude that neither the dimeters-with-an-occasional-monometer (medieval manuscripts; Leo 1878 and most subsequent editions), nor the most common departure from this general principle (introducing more monometers, Fitch 1987, 2002, 2004a,b) correctly reflects the structure of Seneca's anapaests. Most importantly, there is simply no reason to grant a privileged status to dimeter units. Therefore, these approaches cannot be considered satisfactory.

Instead, perhaps the most defining properties of Seneca's anapaests is the overwhelming tendency for there to be metrical synaphy between successive metra. This phenomenon is a very familiar one, as it is present in many pieces of (ancient) lyrical poetry, whether sung or recited: smaller metrical building blocks are 'glued together' to form a single (but internally complex) unit, and a strong effect of rhythmical continuity is created. The acoustic signal is not 'chunked'. Horace is the exception (and the innovator) in treating lyric cola as $\sigma \tau$ í $\chi 01$, not (originally) the rule. In Seneca's tragedies, the picture is hybrid: the poet follows Horatian practice in the case of for instance glyconei and asclepiadei, which show clear signs of being

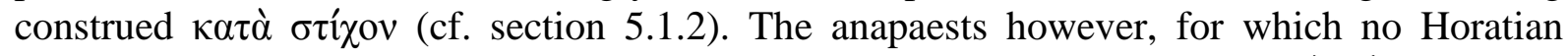
exemplum is available, are construed in a more traditional way, essentially $\kappa \alpha \tau \grave{\alpha} \sigma u ́ \sigma \tau \eta \mu \alpha$, just like the Greek marching anapaests of old. ${ }^{79}$ Pauses are - sparingly but consciously, and therefore also efficiently - inserted to mark strong sense boundaries, to highlight a dramatic climax, and perhaps just to add an element of variation to the composition. ${ }^{80}$

The net result is a tension between the metrical and the rhythmical properties of the anapaestic poems. Seneca cleverly exploits this tension: despite the very simple microstructure of the cantica (a result of the small inventory of atoms on the one hand, (cf. the 5 anapaestic metra listed in (3) at the beginning of this paper), and of the absence of constituents larger than a single metron on the other), their macrostructure is highly unpredictable: this keeps the hearer constantly on guard, and avoids unwelcome

\footnotetext{
${ }^{79}$ It is tempting to relate the predominance of synaphy in Senecan anapaests to the absence of this particular type of metre in the Horatian corpus, but the non-accidental character of this relation is obviously hard (if not impossible) to prove.

${ }^{80}$ The function of pauses in Senecan anapaests seems to some extent similar to the role that catalexis plays in Greek anapaests, which also tend but don't have to coincide with strong syntactic breaks.
} 
repetitiveness. What we get is a composition which is easy to listen to, but never boring or monotonous; which lends itself naturally to long digressions and ecphrases, but does not slow down the narrative beyond necessity; a poem which in the Senecan tragic corpus can be considered an all-round type of metre, equally fit to evoke dawn and sunrise at the beginning of the Hercules Furens as to narrate the dramatic climax of the story of Thyestes, but occupies a position which is quite unique in the entire extant Latin literature. Any attempt to disturb the subtle balance between rhythm and metre, intentionally designed by the poet, by constantly disrupting the rhythmical continuity by means of intrusive structural units for which no empirical motivation exists beyond the (late) medieval manuscripts, will fail to do justice to the true nature of Seneca's anapaests.

Lieven Danckaert

Ghent University (UGent),

Department of Linguistics

Blandijnberg 2

B-9000 Gent

Belgium

Email: Lieven.Danckaert@UGent.be

\section{References}

Balogh, Josef. 1927. "Voces paginarum: Beiträge zur Geschichte des lauten Lesens und Schreibens." Philologus 82: 84-109; 202-240.

Boeckh, August. 1811. Pindari opera quae supersunt recensuit Augustus Boeckhius. Leipzig: Weigel.

Boldrini, Sandro. 1984. Gli anapesti di Plauto: metro e ritmo. Urbino: Pubblicazioni dell'Università di Urbino.

Boldrini, Sandro. 1999. Prosodie und Metrik der Römer (transl. by Bruno Häuptli). Stuttgart: Teubner.

Carlsson, Gunnar. 1927. Die Überlieferung der Seneca-Tragödien: eine textkritische Untersuchung. Lund: Gleerup.

Dale, Amy. 1948. The Lyric Metres of Greek Drama. Cambridge: Cambridge University Press.

Dangel, Jacqueline, ed. 1995. Accius: oeuvres (fragments). Paris: Les Belles Lettres.

Dangel, Jacqueline. 2001. Le poète architecte: arts métriques et art poétique latins. Louvainla-Neuve: Peeters.

Diggle, James, ed. 1981. Euripides fabulae, Vol. 2. Oxford: Clarendon Press.

Dominicy, Marc and Mihai Nasta. 2009. "Towards a universal definition of the caesura." In Towards a typology of poetic forms: from language to metrics and beyond, edited by Jean-Louis Aroui and Andy Arleo, 247-266. Amsterdam: Benjamins.

Donat, Sebastian. 2010. Deskriptive Metrik. Innsbruck: Studienverlag.

Drexler, Hans. 1950. "Caesur und Diaerese." Aevum 24: 332-366.

Fabb, Nigel and Morris Halle. 2008. Meter in Poetry: A New Theory. Cambridge: Cambridge University Press.

Fitch, John. 1987. Seneca's Anapaests: Metre, Colometry, Text and Artistry of the Anapaests in Seneca's Tragedies. Atlanta: Scholar's Press. 
Fitch, John, ed. 2002. Seneca, Vol.8: Tragedies I. Cambridge, MA: Harvard University Press. Fitch, John, ed. 2004a. Seneca, Vol. 9: Tragedies II. Cambridge, MA: Harvard University Press.

Fitch, John. 2004b. Annaeana tragica: Notes on the Text of Seneca's Tragedies. Leiden: Brill. Fortson, Benjamin. 2008. Language and Rhythm in Plautus: Synchronic and Diachronic Studies. Berlin: Mouton de Gruyter.

Fraenkel, Eduard. 1932-33. "Kolon und Satz: Beobachtungen zur Gliederung des antiken Satzes I-II." GöttNachr, Philosophisch-historische Klasse 1932: 197-213; 1933: 319354.

García Novo, Elsa. 1995. "Catalexis, brevis in longo and the Structure of the Greek Stichich Verse: a New Approach." Rendiconti dell'Accademia di Archeologia, Lettere e Belle Arti di Napoli, Società Nazionale di Scienze, Lettere ed Arti 65: 73-94.

Gilliard, Frank. 1993. "More Silent reading in Antiquity: non omne verbum sonabat." Journal of Biblical Literature 112: 689-694.

Grenfell, Bernard and Arthur Hunt, eds. 1906. The Hibeh Papyri, Edited with Translations and Notes by Bernard P. Grenfell and Arthur S. Hunt. London: Egypt Exploration Fund.

Gries, Stefan. 2009. Statistics for Linguistics with R: A Practical Introduction. Berlin: Mouton de Gruyter.

Habinek, Thomas. 1985. The Colometry of Latin Prose. Berkeley: University of California Press.

Hasty, Christopher. 1997. Meter as Rhythm. Oxford: Oxford University Press.

Hayes, Bruce. 1989. "The Prosodic Hierarchy in Meter." In Rhythm and Meter, edited by Paul Kiparsky and Gilbert Youmans, 201-260. San Diego: Academic Press.

Henderson, Jeffrey, ed. 2002. Aristophanes, Vol. 4: Frogs, Assemblywomen, Wealth. Cambridge, MA: Harvard University Press.

Hoche, Max. 1862. Die Metra des Tragikers Seneca: ein Beitrag zur lateinischen Metrik. Halle: Waisenhaus.

Itsumi, Kiichiro. 2007. "What's in a Line? Papyrus Formats and Hephaestionic Formulae." In Hesperos: Studies in Ancient Greek Poetry Presented to M. L. West on his Seventieth Birthday, eds. Patrick Finglass, Christopher Collard and Nicholas Richardson, 306-325. Oxford: Oxford University Press.

Kannicht, Richard. 1976. "Euripidea in P. Hibeh 2. 179." ZPE 21: 117-133.

Jakobson, Roman. 1933. "Über den Versbau der serbokroatischen Volksepen." Archives Néerlandaises de Phonétique Expérimentale 7-9: 135-144.

Jakobson, Roman. 1960. "Linguistics and Poetics." In Style in Language, edited by Thomas Sebeok, 350-377. Cambridge, MA: The MIT Press.

Johnson, William. 2000. "Toward a Sociology of Reading in Classical Antiquity." American Journal of Philology 121: 593-627.

Kassel, Rudolf and Austin, Colin, eds. 1983-. Poetae comici Graeci. Berlin: de Gruyter [= PCG].

Keil, Heinrich, ed. 1855-1880. Grammatici Latini ex recensione H. Keilii I-VIII. Leipzig: Teubner [= GLK].

Kenney, Edward. 1982. "Books and readers in the Roman world." In The Cambridge history of classical literature II: Latin literature, edited by Edward Kenney and Wendell Clausen, 3-32. Cambridge: Cambridge University Press.

Kiparsky, Paul. 1975. "Stress, Syntax and Meter." Language 51: 576-616.

Knox, Bernard. 1968. "Silent Reading in Antiquity." Greek, Roman and Byzantine Studies 9: 421-435. 
Korzeniewski, Dietmar. 1968. Griechische Metrik. Darmstadt: Wissenschaftliche Buchgesellschaft.

Koster, Willem. 1936. Traité de métrique grecque suivi d'un précis de métrique latine. Leiden: Sijthoff.

Leo, Friedrich. 1878. De Senecae tragoediis observationes criticae. Berlin: Weidmann.

Leo, Friedrich. 1878-79. L. Annaei Senecae tragoediae. Berlin: Weidmann.

Liberman, Gauthier. 2005. Réflexions sur les anapestes de Sénèque et la réception des mètres grecs à Rome. Online publication, available at:

http://ars-scribendi.ens-lsh.fr/article.php3?id_article=35\&var_affichage=vo

Luque Moreno, Jesús. 1984. "Sistema y realización en la métrica: bases antiguas de una doctrina moderna." Emerita 52: 33-50.

Luque Moreno, Jesús. 1995. De pedibus, de metris: las unidades de medida en la rítmica y en la métrica antiguas. Granada: Universidad de Granada.

Maas, Paul. 1962. Greek metre (transl. by H. Lloyd-Jones). Oxford: Clarendon Press.

Macleod, Malcolm, ed. 1967. Lucian, vol. 8. Cambridge, MA: Harvard University Press.

Mantke, Joseph. 1957-58. "De Senecae tragici anapaestis." Eos 49: 101-122.

Marx, Wilhelm. 1932. Funktion und Form der Chorlieder in den Senecatragödien. Köln: Kappes.

Matthiessen, Kjeld. 1966. "Rev. Mette 1959, 1963." Gnomon 38: 127-134.

Mette, Hans Joachim, ed. 1959. Die Fragmente der Tragödien des Aischylos. Berlin: Akademie Verlag.

Mette, Hans Joachim. 1963. Der verlorene Aischylos. Berlin: Akademie-Verlag.

Müller, Lucian. [1861] 18942. De re metrica poetarum latinorum praeter Plautum et Terentium libri septem. Leipzig: Teubner.

Münscher, Karl. 1919. "Metrische Beiträge." Hermes 54: 11-45.

Nespor, Marina and Irene Vogel. 2007². Prosodic Phonology (with a New Foreword). Berlin: Mouton de Gruyter.

Nesselrath, Heinz-Günther. 1990. Die attische Mittlere Komödie: ihre Stellung in der antiken Literaturkritik und Literaturgeschichte. Berlin: de Gruyter

Page, Denys, ed. 1972. Aeschyli septem quae supersunt tragoedias. Oxford: Clarendon Press.

Parker, Holt. 2009. "Books and reading Latin poetry." In Ancient Literacies: The Culture of Reading in Greece and Rome Johnson, edited by William Johnson, 186-229. Oxford: Oxford University Press.

Patzer, Harald. 1983. "Metrische Synaphie in iambischen Dimeterreihen der Tragödie (zu Soph. Ant. 855)." In Festschrift Muth, edited by Paul Händel and Wolfgang Meid, 307321. Innsbruck: Institut für Sprachwissenschaft der Universität.

Pretagostini, Roberto. 1974. "Il colon nella teoria metrica." Rivista di Filologia e d'Istruzione Classica 102: 273-282.

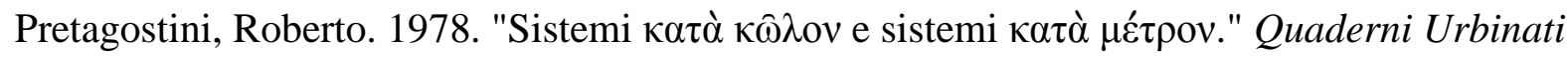
Cultura Classica 28: 165-179.

Raabe, August. 1912. De metrorum anapaesticorum apud poetas graecos usu atque conformatione quaestiones selectae. Strasbourg: Du Mont Schauberg.

Richter, Gustav. 1899. Kritische Untersuchungen zu Senecas Tragödien. Jena: Neuenhahn.

Rossi, Luigi. 1978. "La sinafia." In Studi in onore di A. Ardizzoni, edited by Enrico Livrea and G. Aurelio Privitera, 791-821. Rome: Ateneo e Bizzarri.

Seva, Antoni. 1977. "Els anapests de les tragèdies de Sèneca." Anuario de filología 3: 143 163.

Snell, Bruno. 1957². Griechische Metrik. Göttingen: Vandenhoeck \& Ruprecht.

Soubiran, Jean. 1966. L'élision dans la poésie latine. Paris: Klincksieck.

Sperber, Dan and Deirdre Wilson. 1995². Relevance: Communication and Cognition. Oxford: 
Blackwell.

Stinton, Tom. 1977. "Pause and Period in the Lyrics of Greek Tragedy." Classical Quarterly n.s. 27: 27-66.

Strzelecki, Ladislaus. 1938. De Senecae trimetro iambico quaestiones selectae. Kraków: Academia Polona Litterarum.

Terzaghi, Nicolaus, ed. 1939. Synesii Cyrenensis hymni. Roma: Typis Regiae Officinae Polygraphica.

Tindale, Christopher. 2007. Fallacies and Argument Appraisal. Cambridge: Cambridge University Press.

van Raalte, Marlein. 1986. Rhythm and Metre: Towards a Systematic Description of Greek Stichic Verse. Assen: van Gorcum.

von Wilamowitz-Möllendorf, Ulrich. 1910. Einleitung in die Griechische Tragödie. Berlin: Weidmann.

von Wilamowitz-Möllendorf, Ulrich. 1921. Griechische Verskunst. Berlin: Weidmann.

von Wilamowitz-Möllendorf, Ulrich, ed. 1941. Bucolici Graeci (editio altera correctior).

Oxford: Clarendon Press.

West, Martin. 1977. "Tragica I: Are Anapaestic Dimeters Real?" BICS 24: 89-94.

West, Martin. 1982a. Greek Metre. Oxford: Oxford University Press.

West, Martin. 1982b. Three Topics in Greek Metre." Classical Quarterly n.s. 32: 281-297.

West, Martin, ed. 1990. Aeschyli Tragoediae cum incerti poetae Prometheo, recensuit Martin L. West. Stuttgart: Teubner.

Wilson, Marcus. 1990. "Rev. Fitch 1987." Phoenix 44: 189-194.

Zeleny, Karin. 2008. Itali modi: Akzentrhythmen in der lateinischen Dichtung der augusteischen Zeit (= Wiener Studien Beiheft 32). Wien: Österreichische Akademie der Wissenschaften.

Zwierlein, Otto. 1984. Prolegomena zu einer kritischen Ausgabe der Tragödien Senecas. Wiesbaden: Steiner.

Zwierlein, Otto, ed. 1986. L. Annaei Senecae tragoediae, incertorum auctorum Hercules [Oetaeus] et Octavia. Oxford: Clarendon Press.

Zwierlein, Otto. 1990. "Rev. Fitch 1987." Gnomon 62: 692-696. 